Amasya Ilahiyat Dergisi - Amasya Theology Journal

ISSN 2667-7326 | e-ISSN 2667-6710

Haziran / June 2021, 16: 483-517

\title{
Hayır Kurumlarının Gelirleri ve Bunların Sarf Yerleri
}

\author{
Abdurrahman CANER \\ Dr., Dumlupınar Anadolu İmam Hatip Lisesi \\ Ph.D, Dumlupinar Anatolian religious vocational high school \\ Mersin, Turkey \\ abdurrahmancaner@gmail.com \\ orcid.org/0000-0003-0292-0639 \\ Makale Bilgisi / Article Information
}

Makale Türü / Article Types: Araştırma Makalesi / Research Article

Geliş Tarihi / Received: 11 Ocak / January 2021

Kabul Tarihi / Accepted: 5 Nisan / April 2021

Yayın Tarihi / Published: 30 Haziran / June 2021

Yayın Sezonu / Pub. Date Season: Haziran / June

Sayı / Issue: 16 Sayfa / Pages: 483-517

Atıf / Cite as: Caner, Abdurrahman. "Hayır Kurumlarının Gelirleri ve Bunların Sarf Yerleri [Income of Charitable Foundations and Where to Use Them]". Amasya Illahiyat Dergisi-Amasya Theology Journal 16 (June 2021): 483-517.

https://doi.org/10.18498/amailad.858488.

İntihal / Plagiarism: Bu makale, en az iki hakem tarafından incelendi ve intihal içermediği teyit edildi. / This article has been reviewed by at least two referees and scanned via a plagiarism software.

Copyright (c) Published by Amasya Üniversitesi, İlahiyat Fakültesi / Amasya University, Faculty of Theology, Amasya, 05100 Turkey. All rights reserved. https://dergipark.org.tr/amailad. 
484 | A. CANER / Hayır Kurumlarının Gelirleri ve Bunların Sarf Yerleri

\section{Income of Charitable Foundations and Where to Use Them}

\section{Abstract}

Organizations that aim to serve the society without any financial benefit, and act on a voluntary basis are called charity. Individual efforts were in solving social and familial problems that grew and diversified in the historical process, and as a result, charitable organizations were established. These organizations not only performed important duties in dressing the wounds of societies faced great disasters and calamities, but they also contributed to the development and spread of solidarity and welfare culture. Especially the teachings of the Qur'an, the practices of the Prophet and the Companions caused the rapid spread of the charity in Islamic lands.

The charitable organizations that had been institutionalized over time performed important tasks in many fields ranging from the architectural and aesthetic appearance of Islamic cities to today's municipal services, from all levels of education and training to achieving economic, commercial, political and military goals. Leaders and families of Islamic countries also donated considerable amount of their personal possessions to the services of charity organizations, supported them and facilitated their operations by preparing certain legal regulations. Especially during the time of the Ottomans, these institutions produced unique monuments in Istanbul, Anatolia and Balkan cities, through trust institutions.

The greatest sources of income for active and dynamic charity organizations were undoubtedly zakah, almsgiving, donations and gifts in kind and in cash. The legitimacy and continuity of charities depends on the use of the aforementioned revenues in line with their intended purpose. So that it becomes possible to act upon the Shari'ah rules regarding the giving away the possessions entrusted to them. In this context, the charity income and where the income are expended are of importance. In particular, whether zakah, the area of use of which is directly determined by the Nașs, could be given away to organizations and institutions with a judicial personality. Fuqahā examined the issue within the scope of "fī sabili llāh" which is one of the eight classes to be given more zakah, and in the context of "assignment condition". Most of the fiqh scholars find it unfavorable to give zakah directly to such organizations. Some of the contemporary scholars confined the scope of zakat to the extent of jihad, and some of them approached the issue on the basis of "closeness to Allah" and "utilitas". Those who adopt this last approach expanded the scope of zakah and statüde that zakah can be given 
to charity organizations to support them, and beyond that, a fund can be allocated from the zakah income and loaned to Muslims in the form of karz hasan and in a utilitas-based way who want to expand their business. When the evidence on which the stated opinions were based was examined, it was observed that the last opinion is weak. However, considering the practices of the Prophet and the Companions and pondering upon the broad meaning of jihad, it has been concluded that charity institutions can be supported with zakah income under certain conditions. The issue has been tried to be analyzed within the framework of the conceptual borderings of "attorney" and "client" regarding the use of income such as charity, grants and donations, which have a wider area of use than zakah does. Therefore, it is generally accepted that the will and declaration of a grantee or a donor is decisive, however, the differences between in-kind and in-cash aids have also been pointed out. In order for the charity officials to be able to act against the will of a donor, it is stipulated that the officials should know more than the donor in which areas the needs and interests of the society are concentrated, and this change of disposition is also subject to the knowledge and permission of the donor.

The aim of our study is to examine, within the framework of Islamic law, the views of the fuqahā and the evidence on which these opinions are based on issues such as where the income of the charity organizations, especially zakat and charity could be spent, and who has the priority to receive the charity, whether the aid in kind and in cash could be used outside its purpose, what the responsibilities of the institution officials are, and as of which types of contract the aids are seen, and what the binding force of these contracts is; and, in the end it contributes to the studies made or will make about the issue.

Keywords: Fiqh, Charity Organization, Zakah, Sadaqah, Disposition.

\section{Öz}

\section{Hayır Kurumlarının Gelirleri ve Bunların Sarf Yerleri}

Herhangi bir maddi çıkar gütmeksizin topluma hizmet sunmayı amaçlayan ve gönüllülük esasına dayanan yapılar, hayır kurumları/müesseseleri olarak isimlendirilmiştir. Tarihi süreçte büyüyüp çeşitlenen toplumsal ve ailevi sorunlara karşı ferdi gayretler yetersiz kalmış, bunun sonucunda hayır müesseseleri kurulmuştur. Bu müesseseler büyük felaket ve musibetlere maruz kalan toplumların yaralarını sarmada önemli görevler icra ettiği gibi dayanışma ve yardımlaşma kültürünün gelişmesine ve yayılmasına da katkı sağlamıştır. 
486 | A. CANER / Hayır Kurumlarının Gelirleri ve Bunların Sarf Yerleri

Özellikle Kur'an'ın öğretileri, Hz. Peygamber ve sahabe uygulamaları hayır kurumlarının İslam beldelerinde hızla yayılmasına neden olmuştur.

Zaman içerisinde kurumsallaşan hayır müesseseleri, kurdukları yapılarla İslâm şehirlerinin mimârî ve estetik görünümünden, bu günkü belediye hizmetlerine, eğitim ve öğretimin tüm kademelerinden, iktisadi, ticari, siyasi ve askeri hedefleri gerçekleştirmeye varıncaya kadar birçok alanda önemli görevler icra etmişlerdir. İslam ülkelerinin liderleri ve aileleri de hayır kurumlarının faaliyetlerine kendi şahsî varlıklarından hatırı sayılır oranlarda katkıda bulunmuş, onları desteklemiş ve bazı kanuni düzenlemeler yaparak kolaylık sağlamışlardır. Bilhassa Osmanlılar zamanında bu kurumlar, vakıflar aracılığıyla başta İstanbul olmak üzere Anadolu ve Balkanlar'da şehirlerinde eşsiz eserler ortaya koymuşlardır.

Aktif ve dinamik olan hayır kurumlarının en büyük gelir kaynakları şüphesiz ki başta zekât olmak üzere sadaka, hibe ve teberru şeklinde yapılan aynî ve nakdî yardımlarla olmuştur. Hayır kurumlarının meşruiyeti ve devamlılı̆̆ zikredilen gelirlerin amacına uygun olarak kullanılmasına bağlıdır. Bu meyanda hayır kurumlarının gelirleri ve bu gelirlerin sarf alanı önem arz etmektedir. Özellikle sarf alanı doğrudan nasla belirlenen zekâtın hükmi kişiliğe sahip yapı ve kurumlara verilip verilmeyeceği önemsenmiş ve tartışılmıştır. Fukaha meseleyi daha çok zekât verilecek sekiz sınıftan biri olan "fîsebîlillâh" kapsamında ve "temlik şartı" bağlamında incelemiştir. Fâkihlerin çoğunluğu zekâtın doğrudan bu tür yapılara verilmesini mahzurlu görmüştür. Muasır âlimlerden bazıları zekâtın sarf alanını cihâdın kapsamıyla sınırlandırmış, bir kısmı da "Allah'a yakınlık" ve "maslahat" temelinde meseleye yaklaşmıştır. Bu son yaklaşımı benimseyenler, zekâtın sarf alanını iyice genişletmiş, hayır kurumlarının desteklenmesi için onlara zekât verilebileceğini ve bunun da ötesinde zekât gelirlerinden bir fon oluşturulup bu fon aracıllğıyla işlerini genişletmek isteyen Müslümanlara karz-1 hasen şeklinde ve maslahat temelinde borç verilebileceğini ifade etmişlerdir. Belirtilen görüşlerin dayandığı deliller incelendiğinde son görüşün zayıf kaldığı müşahede edilmiştir. Ancak Hz. Peygamber ve sahabe uygulamaları göz önünde bulundurulduğunda ve cihadın geniş manası düşünüldügüunde hayır kurumlarının belli şartlar muvacehesinde zekât gelirleriyle desteklenebileceği kanaatine varılmıştır. Zekâta nisbetle sarf alanı daha geniş olan sadaka, hibe ve teberru gibi gelirlerin sarf alanı konusunda ise "vekil" ve "müvekkil" çerçevesinde mesele tahlil edilmeye çalışılmıştır. Dolayısıyla tasadduk, hibe ya da teberruda bulunanın irade ve beyanının 
belirleyici olduğu genel olarak kabul edilmiş, bununla beraber aynî ve nakdî yardımların arasındaki farklara da dikkat çekilmiştir. Teberruda bulanan kişinin iradesine muhalif hareket edebilmek için hayır kurumu yetkililerinin, ihtiyaç ve maslahatın hangi alanda yoğunlaştığını teberru sahibinden daha fazla bilmeleri şart koşulmuş, bu tasarruf değişikliği de yine teberru sahibinin bilgisine ve iznine tabi tutulmuştur.

Çalışmamızın amacı İslam hukuku çerçevesinde bu yapıların gelirlerinden özellikle zekât ve sadakanın nerelere sarf edileceği, önceliğin kimlerde olduğu, aynî ve nakdî yardımların amacı dışında kullanılıp kullanılmayacağıı, müessese yetkililerinin sorumluluk alanları, yapılan yardımların hangi akit çeşidine dâhil olduğu ve bu akitlerin bağlayıcılığı gibi mevzularda fukahânın görüşlerini ve bu görüşlerin dayandığı delilleri incelemek ve mevzu ile ilgili yapılan çalışmalara katkı sunmaktır.

Anahtar Kelimeler: Fıkıh, Hayır Müessesesi, Zekât, Sadaka, Sarf

\section{Giriş}

İslam, yardımlaşma ve dayanışma temelinde bir toplum inşa etmeyi hedeflemiş, bunun için bazı prensipler vazetmiştir. Bu manada bütün Müslümanları kardeş ilan etmiş ${ }^{1}$ bir binanın tuğlaları gibi birbirlerine kenetlenmelerini onlardan talep etmiş, ${ }^{2}$ sıkıntı ve problemlerini paylaşmalarını tavsiye etmiştir. ${ }^{3}$ Aynı şekilde yapılan iyiliğin boşa gitmeyeceğini, iyilik yapanın mutlaka karşılığını göreceğini haber vermiş, ${ }^{4}$ bu haberin neticesi olarak Müslümanların hayır ve iyilikte birbirleriyle yarışmaları gerektiğini belirtmiştir. ${ }^{5}$ Özellikle Hz. Peygamber'in süreklilik arz eden ve öldükten sonra hayrı devam eden

1 Bk. el-Hucurat 49/10.

2 Bk. Ebû Abdillâh Muhammed b. İsmâil b. İbrâhim el-Buhârî, el-Câmiu's-sahîh (b.y.: Dâru Tavki'n-Necât, 1422), "salat”, 87; Ebu'1-Hüseyn Müslim b. el-Haccâc b. Müslim el-Kuşeyrî, Sahîhu Müslim (Beyrût: Dâru İhyâi't-turâsi'l-Arabiyye, ts.). "Birr", 17.

3 Bk. Ebû Dâvûd Süleymân b. el-Eş’as b. İshâk es-Sicistânî, Süneni Eb̂̂ Dâvûd (Beyrut: Mektebetu'l-asriyye, ts.), "Zekât", 41; Ebû 'İsâ Muhammed b. 'İsâ b. Sevre et-Tirmizi, Sünen, thk. Ahmed Muhammed Şâkir - Ahmed Fuâd Abdulbâkî (Mısır: Matb’atu Mustafa el-Bâbî, el-Halebî, 1975), “Ebvâbü sifeti'l-kıyâme”, 18.

4 Bk. Zilzâl 99 /7-8.

5 Bk. el-Bakara 2/148. 
488 I A. CANER / Hayır Kurumlarının Gelirleri ve Bunların Sarf Yerleri

sadaka-i câriye ${ }^{6}$ gibi iyiliklerden bahsetmesi $^{7}$ ve hayatında buna yer vermesi $^{8}$ Müslümanların mallarının bir kısmını hayır yolunda teberru etmelerine sebep olmuş ve akabinde daha çok vakıf şeklinde hayır kurumlarının oluşmasına zemin hazırlamıştır. Şüphesiz zekât ve sadaka malları, hayır kurumlarının en önemli gelir kalemleri arasında yer almıştır. Bununla birlikte zekât gelirlerinin nerelere ve nasıl sarf edileceğiyle ilgili tartışmalar gündemi meşgul etmiştir. Aynı şekilde hayır kurumlarına yapılan aynî ve nakdî yardımların sarfı konusunda teberru sahiplerinin ve onların vekili konumunda olan kurumun yetki alanları tartışılmıştır. Bu manada yapılan bağışın hangi akit çeşidine dâhil olduğu, teberruun bağlayıcılığı, hayır kurumlarının alım-satımla ilgili yetkileri, kurum yetkililerinin kendilerine verilen yetkiyi aşma durumlarının olup olmadığı, hayır kurumu mallarından borç verilip verilemeyeceği, öncelikli sarf alanları ve aynî malların amacı dışında kullanılıp kullanılmayacağı gibi meseleler İslam hukukçuları tarafından önemsenmiştir.

Ayasofya Camii'nin müzeden tekrar aslî hüviyetine kavuşması neticesinde ortaya çıkan tartışmalar, konunun güncelliğini koruduğunu göstermektedir. Bu çalışmada ilmi tartışmalara katkı sunmak amacıyla ve İslam hukuku çerçevesinde konu incelenmeye çalışılacaktır. Ancak hayır kurumlarını bütün yönleriyle ele almak bir makale çalışmasına sığmayacağından mevzu, hayır kurumlarının sarf alanıla sınırlandırılacaktır. Bununla beraber konunun daha iyi kavranması için bağlantılı diğer başlıklara da kısaca temas edilecektir. Çalışmanın çerçevesini belirlemek adına önce hayır kurumlarının ortaya çıkışı ve hukuki statüsü ele alınacak, akabinde bu kurumların gelirleri ve bu gelirlerin sarf alanları konusundaki tartışmalara yer verilecek ve değerlendirmelerde bulunulacaktır.

6 Sürekli ve kalıcı hayırlara sadaka-i câriye denir. Bk. Ali Duman, "Sadaka", Türkiye Diyanet Vakfi İslam Ansiklopedisi (İstanbul: TDV Yayınları, 2008), 35/383-384.

7 Bk. Müslim, "Hibât", 6; Ebû Dâvûd, "Vasâyâ", 14; Tirmizi. "Ahkâm", 36; Ebû Abdirrahman Ahmed b. Şuayb b. Ali en-Nesâî, Sünen, thk. Abdulfettâh Ebu Gudde (Haleb: Mektebetü'1-matba'ati'l-İslâmiyye, 1986), "Vasâyâ", 8.

8 Yasin Yılmaz, "Vakıf Kurumunun Dayandığı Temel Referanslar ve Zürrî Vakıfların Vakıf Sistemindeki Yeri", Dini Araştırmalar 17/44 (Haziran 2014), 6. 


\section{Hayır Kurumlarının Ortaya Çıkışı ve Hukuki Statüsü}

Meyletme ve iki durumdan birini diğerine tercih etme manasına gelen hayır kelimesi, zaman içerisinde fazilet ve erdem manalarını da ihtiva edecek şekilde kullanılmıştır. ${ }^{9}$ Müessese kelimesi ise belirli hedefleri gerçekleştirmek üzere özel bir idareye verilmiş, belli değer ve esaslar üzerine kurulmuş, düzenlenmiş toplu işler için kullanılır. ${ }^{10}$ Buna göre belli sayıdaki kişilerin bir araya gelmesiyle meydana gelen ve kâr amacı gütmeden halkın maslahatını üstlenmiş meşru hedefleri gerçekleştirmek üzere kurulan müstakil hükmî kişiliklere sahip yapılara hayır müessesesi denir. ${ }^{11}$

İslam âleminde tarihi seyir içerisinde hayır müesseseleri baştan beri var olagelmişlerdir. Bunda İslam dininin doğrudan etkisi bulunmaktadır. Nitekim İslam'ın ortaya koyduğu zekât ve sadaka-i câriye gibi düzenlemeler hayır kurumlarının çok erken dönemlerden itibaren oluşmasına zemin hazırlamıştır. Hayır ve iyiliğin kalıcı ve sürekli olması

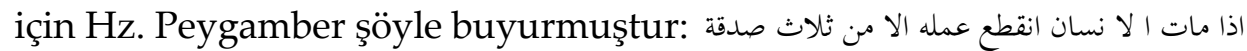
جارية أو علم ينتفع به أو ولد صالح يدعو له "Insanoğlu öldüğ̈̈ zaman, bütün amellerinin sevabı sona erer. Şu üç şey bundan müstesnadır: Sadaka-i câriye, istifade edilen

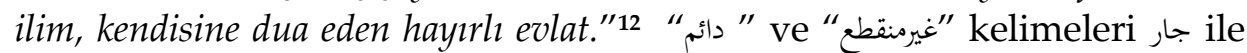
aynı manayı ifade ettiği halde hadiste bu iki ifade yerine "câr" kelimesi kullanılmıştır. "cer" kelimesi, azalmayan bir süreklilik manasını ihtiva ettiği için tercih edilmiş ve böyle bir hayrın kesilmesinin ise söz konusu olamayacağına vurgu yapılmıştır. Aynı şekilde hadiste, mescit, kuyu, Mushaf ve faydalı kitaplar gibi insanların çoğu zaman kendilerinden yararlandıkları şeylerin vakfedilmesini sevdirmeye işaret vardır. Zira bu

9 Ebû Abdirrahmân el-Halil b. Ahmed b. Amr b. Temîm el-Ferâhîdî, Kitabu'l-'Ayn (Beyrut: Mektebetü Lübnân Nâşirûn, ts.), "Hyr", 1/455-456; Cemâlüddîn Muhammed b. Mükerrem b. Ali b. Ahmed er-Rüeyfîi İbn Manzûr, Lisânü'l-Arab (Kahire: Dâru'lMe'ârif, 1119), “Hyr", 2/1298-1299.

10 Muhammed Nâcî İbn 'Atiyye, el-Binâu'l-müessisiyyu fi'l-münezzimâti'l-hayriyye (Beyrut: Daru İbn Hazm, 1423), 7; Diâ Âdil Kâsım es-Suknâ, el-Muessesâtu'l-hayriyye hukmuha ve devâbitu'l-kâimîn aleyha ve hududu salahiyetihim (Gazze: el-Câmiatu'l-İslâmiyye, Yüksek Lisans Tezi, 2012), 18.

11 İbn 'Âtiyye, el-Binâ, 8; Hanîn Dît, Devru'l-müessesâtü'l-hayriyye fi't-tenmiyeti'l-ictimâiyye (Cezâyir: Câmi'atu eş-Şehîd Hama, Yüksek Lisans Tezi, 2015), 21.

12 Müslim, "Hibât", 6; Ebû Dâvûd, "Vasâyâ", 14; Tirmizi, "Ahkâm”, 36; Nesâî, "Vasâyâ", 8. 
sayılanlara insanların her zaman ihtiyacı vardır. Dolayısıyla Müslümanlar kendi rızalarıyla mallarını hayır yolunda vakfederek herkesin ondan faydalanmasını sağlayacak, karşılığında ahirette kurtuluşlarına vesile olacak bol sevaba nail olacaklardır. Bu sebeple zengin Müslümanlar, birçok iyilikten yararlanmak adına dünya ve ahiret hayrına yönelik aynî mallarını bağışlama konusunda istekli olmuşlardır. Bağışlanan malın satılmaması, hibe edilmemesi, miras birakılmaması ve onun menfaatinin sadaka-i câriye olarak toplum maslahatı için kullanılması dünyaya yönelik hayrı ifade ederken, onun sevabının ölümden sonra bağışlayana fayda sağlaması ise ahirete yönelik hayır olarak ifade edilmiştir.

Hayır kurumları, hukuki özellikleri bakımından birbirinden farklılı arz etse de genel anlamda teberru akitleri grubunda değerlendirilmiştir. Fakihler, teberru akitlerinin çeşitlerini de içine alacak şekilde kapsamlı bir tanım ortaya koymamakla birlikte her bir çeşidi için ayrı ayrı tanım yapmışlardır. Buradan hareketle teberru akitleri için şöyle genel bir tanım ortaya konabilir: Allah'a yakın olmak, onun rızasını kazanmak amacıyla kişinin kendi hür iradesiyle karşılıksız olarak bağışladığ1 ve mali muamelelerin tüm çeşitlerini kapsayacak şekilde düzenlenen akitlere denir. ${ }^{13}$

Teberru akitlerinin birçok çeşidi bulunmaktadır. Vakıf, vasiyet, hibe, ariyet, karz ve geri dönüşü olmayacak şekilde yapılan kefalet akdi bunlardan bazılarıdır. ${ }^{14}$ Burada özelikle vakıf çatısı altında hayır müesseselerinin yaygın olarak faaliyet göstermesi nedeniyle vakfın tanımı, meşruiyeti, çeşitleri ve onlardan da konumuzla ilgili olanların tasarruf yetkisi ve alanları üzerinde durulacaktır.

\subsection{Vakıf}

Menetmek hapsetmek engellemek, tutmak anlaminda masdar bir kelime olan vakıf, aynı zamanda ism-i meful manasını da ihtiva etmektedir. ${ }^{15}$ Vakfa konu olan şeyin niteliği nedeniyle farklı tanımlar ortaya konulmuştur. Ebû Hanife (öl. 150/767) vakfı; “Aynî bir malın

13 Arif Atalay, Teberru Akitlerinde Kabz, Universal Journal of Theology 5/1 (Haziran 2020), 3.

14 Zeynüddîn b. İbrâhim b. Muhammed el-Misrî, el-Bahru'râik şerhu Kenzi'd-dekâik (b.y.: Dâru'l-kitâbi'l-İslâm, ts.), 4/401; Ebû Bekr Şemsü'l-eimme Muhammed b. Ebî Sehl Ahmed es-Serâhsî, el-Mebsût (Beyrut: Dâru'l-Ma'rife, 1993), 26/27.

15 İbn Manzûr, “Vkf”, 6/4898. 
mülkiyetinin vakfeden kişiye ait olmak üzere menfaatinin tasadduk edilmesi"16 şeklinde tanımlamıştır. Bu tanıma göre vakfedilen malın mülkiyeti vakfeden kişide olmakla beraber onun tasarruf yetkisi engellenmiş olmaktadir. Ebû Yusuf (öl. 182/798) ve Muhammed'e (öl. 189/805) göre vakıf; "vakfeden kişinin mülk olan aynî bir malın mülkiyetini Allah'a ait olmak üzere menfaatini insanlara veya sevdiği kişilere tasadduk etmesidir."17 Bu tanıma göre vakfedilen aynın mülkiyeti Allah'a geçmiş olmaktadır. Mâlikî mezhebinde vakıfla ilgili yaygın tanım: "takdîren de olsa mülkiyeti vâkıfta kalmak üzere bir şeyin menfaatinin var olduğu sürece teberru edilmesi" 18 şeklindedir. Mâlikîlerin bu yaklaşımı mülkiyetin sahibinde kalması yönüyle Ebû Hanife'nin tanımına benzemektedir. Şâfiî ve Hanbelîlerin tanımlarında ise mülkiyetin kimde kalacağı açık değildir. Örneğin Şâfî̂lerden Remlî (öl. 957/1550), vakfın tanımını şu şekilde yapmaktadır: "mevcut mubah bir harcama için sahibinin tasarruf yetkisinin kesildiği ancak gözetiminin sürdüğ̈̈ aynî bir malın engellenmesidir. ${ }^{19}$ Yapılan tanımlarda iki özellik dikkat çekmektedir. Bunlar, vakfedilen malın sahibi tarafından tasarruf yetkisinin engellenmesine karşılık gözetiminin devam etmesi ve vakıf malının menfaatinin vakfedilen kişiler lehine tasadduk edilmesidir. Bu ortak noktalardan hareketle İbn Kudâme (öl. 620/1223) vakıf hakkında, "Aslın tahbis edilmesi, semerenin ise hayır için serbest bırakılmasıdır" 20 demiştir. Âlimler tüm bu değerlendirmelerin sonucunda vakfı: "Bir malın mâliki tarafindan dinî, içtimâ̂ ve hayrî bir gayeye ebediyen tahsisi" 21 olarak tanımlamışlardır.

16 Burhânüddîn Ali b. Ebîbekr b. Abdülcelil el-Merğînânî, el-Hidâye fî şerhi Bidâye, thk. Talâl Yusuf (Beyrut: Dâru İhyâ, ts.), 3/15.

17 Alâuddîn Ebû Bekr b. Mes'ûd b. Ahmed el-Kâsânî, Bedâiu's-senâi' fî̀ tertîbi'ş-şerâi' (Beyrut: Dâru'l-kutubi'l-ilmiyye, 1986), 6/220; Süleyman b. Câsir el-Câsir, Mesârifu'lvekf fi'l-kadim ve'l-hadîs (Riyâd: Medâru'l-vatan li'n-neşr, 2014), 9.

18 Muhammed b. Abdullâh el-Harşî, Şerhu muhtasar Halil li'l-Harşî (Beyrut: Dâru'l-fikr, ts.), 7/102.

19 Şihâbuddîn Ahmed b. Ahmed b. Hamza er-Remlî el-Menûfî el-Ensârî, Nihâyetu'lmuhtâc ilâ şerhi'l-Minhâc (Beyrut: Dâru'l-fikr, 1984), 6/67.

20 Ebû'l-Ferec Şemsuddîn Abdurrahman b. Muhammed b. Ahmed el-Makdisî, Şerhu'lkebîr alâ metni'l-mukni' (b.y.: Dâru'l-kitâb, ts.), 4/18.

21 Câsir, Mesârifu'l-vekf, 10. 
492 I A. CANER / Hayır Kurumlarının Gelirleri ve Bunların Sarf Yerleri

Hz. Peygamber'in şahsi eşyalarından geride bıraktıklarını vakfettiğine dair rivayetler, ${ }^{22} \mathrm{~Hz}$. Ömer (öl. 23/644), Hz. Osman (öl. 35/656), Hz. Ali (öl. 40/661) ve Halid b. Velid (öl. 21/642) gibi meşhur sahabelerin savaş ganimetlerinden elde ettikleri değerli araziler ile satın aldıkları su kuyuları savaş aletleri, atlar ve ev eşyaları gibi malları vakfettiklerine dair haberler, ${ }^{23}$ vakıf mefhumunun Hz. Peygamber ve sahabe uygulamalarına dayandığını göstermektedir.

İslam ülkelerinin bütününe yayılan vakıflar, şehirlerin estetik görünümünden insanların eğitim ve öğrenimine, fakir ve yoksulların ihtiyaçlarının karşılanmasından bu günkü belediyelerin yaptığı temel hizmetlere varıncaya kadar birçok önemli roller üstlenmiştir. Nitekim İslam ülkelerinde şehirlerin merkezinde yer alan mescit ve camiler, mektep ve medreseler, imaretler, tekkeler, hankah ve zâviyeler, kütüphane, misafirhâne, hastahâne ve çeşmeler, hamamlar ve makbereler, yollar, köprüler ve kervansaraylar, vakıf hizmetlerinin bir tezahürü olarak ortaya çımıştır. ${ }^{24}$

Son derece işlevsel olan vakıflar özellikle Osmanlılar zamanında daha kurumsal bir yapıya bürünmüştür. Osmanlı devletinin hızlı yayılma süreci olan XV ve XVI yüzyıllarda vakıflar, yeni fethedilmiş yerlerin İslamlaştırılmasında önemli görevler üstlenmiştir. Zira sınır bölgelerine gönderilen sufi ve dervişlerin eğitim, tarımsal ve ticari faaliyetlerinin finansmanı vakıflar tarafından karşılanmış ve böylelikle maddi fetihler, manevi fetihlerle desteklenmiştir. ${ }^{25}$

Temelde hayır kurumu niteliği taşıyan vakıflar genellikle tek taraflı hukuki işlem olarak kabul edilmişlerdir. ${ }^{26}$ Dolayısıyla vakfedilen şeyin hukuki geçerlilik kazanabilmesi için sadece vakfeden kişinin icabı yeterli görülmüştür. Hanefîlere göre bu icap sözlü olmak durumundadır. ${ }^{27}$

22 Adbullah b. Nâsır es-Sudhân, Tevcîhu Mesârifi'l-vakf, nahve telbiyeti ihtiyâcâti'l-müctema' (Mekke-i Mükerreme: y.y., 2006), 11; el-Câsir, Mesârifu'l-vekf, 14.

23 Kâsânî, Bedâiu's-senâi', 6/218; Hacı Mehmet Günay, "Vakıf", Türkiye Diyanet Vakfı İslam Ansiklopedisi (İstanbul: TDV Yayınları, 2012), 42/475-479.

24 Mehmet Bayyiğit, Sosyal Yardımlaşma ve Dayanışma Kurumu Olarak Vakıflar, Selçuk Üniversitesi İlahiyat Fakültesi Dergisi 11 (2001), 62.

25 Nazif Öztürk, "Evkâf-1 Hümâyun Nezâreti”, Türkiye Diyanet Vakfı İslam Ansiklopedisi (İstanbul: TDV Yayınları, 1995), 11/522.

26 Serahsî, el-Mebsût, 12/34; Kâsânî, Bedâiu's-senâi', 6/218; İbn Kudâme, el-Muğnn̂, 6/5.

27 Kâsânî, Bedâiu's-senâi', 6/221. 
Şâfîiler icabın yazılı olarak da yapılabileceğini ifade ederken ${ }^{28}$ Mâlikî ve Hanbelîler, bunun örfi bir tarzla da olabileceğini ileri sürmüşlerdir. ${ }^{29}$ İcap gerçekleştikten sonra ondan rücu etmenin mümkün olup olmadığı diğer bir ifadeyle vakıf işleminin bağlayıcılığı tartışılmıştır. Âlimler, konuyla ilgili farklı yaklaşımlar sergilemiştir. Ebu Hanife, vakıf işlemini ilke olarak lazım olmayan ariyet akdine benzeterek onun bağlayıcı olmadığı dolayısıyla vâkıfın istediği zaman bundan vazgeçebileceği görüşünü savunmuştur. ${ }^{30}$ Ebû Yusuf, vakfi, derhal lüzum gerektiren köle azat etme işlemine benzeterek bundan rücu etmenin mümkün olmadığını ileri sürmüştür. Şafii ve Hanbelîlerin çoğunluğu konuyla ilgili Ebû Yusuf'un görüşüne katılmışlardır. ${ }^{31}$ İmam Muhammed ve Mâlikîlerin çoğunluğu ise vakfı sadakaya benzeterek genel anlamda bağlayıcı olduğunu ancak bağlayıcılığın gerçekleşebilmesi için onun teslimini şart koşmuşlardır. ${ }^{32}$ Şu var ki amacına uygun olarak değişikliğe uğrayan, yetkili kişilerce karara bağlanan, kuruluş amacına uygun olarak yararlanılan vakıfların bağlayıcı olup bundan rücu edilemeyeceği konusunda ittifaktan bahsetmek mümkündür. ${ }^{33}$

Hanefî, Şâfiî ve Hanbelî mezheplerinin çoğunluğuna göre vakfedilen malın ayn ${ }^{34}$ olması gerekir. ${ }^{35}$ Çünkü ancak süreklilik ve ebedilik özelliği olan şeyler vakfedilebilir. Bu da aynî mallarla mümkün olabilmektedir. Mâlikîler ise menfaatlerin de vakfedilebileceği görüşündedir. ${ }^{36}$ Ayrıca vakfedilecek aynın kişinin kendi mülkiyetinde

28 Takiyüddîn Osman b. Selâhiddîn Abdirrahman b. Mûsâ eş-Şehrezûrî, Fetâvâ ibn Salâh (Beyrut: Mektebetu'l-ulum, 1407), 319, 397.

29 Harşî, Muhtasar, 7/88; İbn Kudâme, el-Muğnn̂े, 6/7.

30 Merğinânî, el-Hidâye, 3/15.

31 Ebu'l-Hasen Ali b. Muhammed b. Habîb el-Basrî el-Mâverdî, el-Hâvi'l-Kebîr (Beyrut: Dâru'l-kutubi'l-ilmiyye, 1999), 7/512; İbn Kudâme, el-Mŭgnhî, 5/255.

32 Harşî, Muhtasar, 7/88-89.

33 Merğinâni, el-Hidâye, 3/19; Mâverdî, el-Hâvi'l-Kebîr, 7/512; İbn Kudâme, el-Muğn̂̂, $5 / 255$.

34 Ayn: Canlı cansız, ölçülen ve tartılan belirlenmiş mallar ile sayılıp ayrılmış para ve belirlenmiş ticari eşyaya denir. Hayreddin Karaman, "Ayn", Türkiye Diyanet Vakfı İslam Ansiklopedisi (İstanbul: TDV Yayınları, 1991), 4/257-258.

35 Serahsî, el-Mebsût, 12/28; Ebû Zekeriyyâ Yahya b. Şeref b. Mürî en-Nevevî, el-Mecmu' şerhu'l-Muhezzeb (b.y.: Dâru'l-fikr, ts.), 15/327; İbn Kudâme, el-Muğgn̂, 12/28.

36 Harşî, şerhu Muhtasar, 7/78. 
belirli ve mübah olması konusunda ittifak edilmiştir. ${ }^{37}$ Bununla beraber İmam Muhammed ve Hanbelîlerin bir kısmına göre vakfedilen ayn üzerinde bulunan, ebedilik ve süreklilik özelliği olmayan bina, tarım aletleri hatta at ve silah, balta, Mushaf, kitap, kap-kacak gibi insanların ihtiyaç duyduğu eşya ve hayvanlar da ayna bağlı olarak vakfedilebilir. ${ }^{38}$

\subsection{Vakıf Çeşitleri}

Fıkıh usulü eserlerinde birçok vakıf çeşidine yer verilmiştir. Vakıflar malın mülkiyeti açısından sahih-gayr-i sahih olmak üzere iki kategoride incelenmiştir. Konusu mülk, menkul-gayr-i menkul ve arazi olan vakıflar sahih vakıf olarak isimlendirilmiştir. Vakıf denince ilk akla gelen de bu çeşit vakıflardır. Mülkiyeti devlete kalmak, gelirleri ise belli guruplara verilmek üzere tahsis edilmiş mülkler için kurulan yapılara gayr-i sahih vakıflar denildiği gibi irsâdî vakıflar da denilmiştir. Bu tür vakıflar, gerçekte mülk özelliği taşımadığı için bu şekilde isimlendirilmiş ancak hukuki geçerlilikleri kabul edilmiştir. Yine vakıflar yararlananlar açısından, hayri ve zürrî kısımlara ayrılmıştır. Doğrudan hayır maksadiyla kurulan; fakir, yolcu ve talebe gibi belli kesimlere hitap eden vakıflar bu guruba dâhil edilmiştir. Akraba ve hısım ihtiyaçlarının önceliğinin şart koşulduğu vakıflara da zürri vakıflar denilmiştir. Bu tür vakıfların meşruluğu tartışılmış olsa da çoğu ulema tarafından caiz görülmüş ve özellikle Osmanlı toplumunda yaygın olarak uygulanmıştır. Aynı şekilde vakıflar, kendilerinden yararlanma biçimi yönünden aynı ile faydalanılanlar ve aynı ile faydalanılmayanlar şeklinde ikili tasnife tabi tutulmuştur. Aynı ile faydalanılan vakıflara müessesât-ı hayriyye ya da hayrat $^{39}$ adı verilmiştir. Bunlar da ibadet yeri, çeşme, misafirhane, kütüphane, köprü ve mezarlık gibi herkesin faydalanabileceği vakıflar ile imaret hastane ve dulhâne ${ }^{40}$ gibi belli gurupların yararlandığı vakıflar şeklinde alt guruplara ayrılmıştır. Ayn ile faydalanılmayan vakıflar ise

37 Câsir, Mesârifu'l-vakf, 25-29.

38 Merğinâni, el-Hidâye, 3/19; Cemâlüddîn İbrâhim b. Ali b. Yûsuf eş-Şînâzî, el-Muhezzeb fî fikhi'l-İmâm eş-Şâfî̀, thk. Muhammed ez-Zuceylî (Beyrût: ed-Dâru'Şâmiyye 1992), 2/326; İbn Kudâme, el-Mŭ̆nî, 6/29.

39 Mâverdî, el-Hâvi'l-kebîr, 13/307.

40 Dulhâne: 19. Yüzyılın ikinci yarısından sonra Osmanlı imparatorluğunun toprak kayıplarına bağlı olarak İstanbul ve Anadolu'ya göç eden kimsesiz dul kadınlar ile çocukların bakımı için kurulmuş hayır müessesesine denir. Bk. Abdullah Bay, Türkiye Mecmuası 27/1, (2017), 47-64. 
kendilerinden doğrudan değil, gelirleri aracılığıyla yararlanılan vakıflardır. ${ }^{41}$ Çalışmamız daha çok bir hayır müessesesi olarak vakıfları ve onun menfaatini diğer bir ifadeyle vakıf gelirlerinin harcama yerlerini esas aldığından burada sahih vakıfların hayri özelliği olan kısmı ve aynî olmayan vakıfların menfaatinin nerelere harcanması gerektiği üzerinde durulacaktır. Vakfın yönetilmesi, işletilmesi ve menfaatinin dağıtılması ile ilgili hususlarda vakfedenin iradesi esastır. Hatta bu konuda "Vakfedenin şartı şâriîn nassı gibidir" 42 denilmiştir. Dolayısıyla ayn olan bir malı vakfeden kişi onu kendi aile fertlerinin yararına vakfedebileceği gibi menfaatini de zengin- fakir herkesin yararına sunabilir. Şu var ki vakıflar, temelde bir hayır müessesesi olduklarından kuruluş amacına aykırı olarak onun menfaati dinen yasak olan yerlere harcanamaz ve vâkıfın iradesine aykırı olarak kullanılamaz. Yine lehine vakıf yapılan kişi/ler, belli olan fakir bir grup ya da kesim olabileceği gibi mescit, medrese, hastane, yol, çeşme, kütüphane gibi kurumlar hatta hayvanlar da olabilir. Mescit, medrese gibi yararlanma biçimi ayn olan kuruluşlar, umumun menfaatine açıktır. Yetimhane, imaret, hastane ve dulhâne gibi hayır kurumları ise doğal olarak umuma değil, sadece fakirlere açıtır.

\section{Hayır Kurumlarının Gelirleri}

Tarihten günümüze kadar geçen süreçte hayır kurumlarının toplumda birçok önemli iş ve görevler üstlendiği bir vakıadır. Dul kadınların nafakasını temin etmek, mescitleri imar ve tamir etmek, borçluların borçlarını ödemek, bekâr olanları evlendirmek, şehit, gazi ve esir düşen kişilerin geride bıraktıkları ailelere bakmak, ilim talebelerine yardımcı olmak, oruç tutanlara iftar vermek, Kur'an-1 Kerim'in ezberlenmesine yardımcı olmak ve diğer ihtiyaç sahiplerine yardımcı olmak bunlardan bazılarıdır. ${ }^{43}$ Tüm bunların masrafları daha çok özel teşebbüs konumunda olan hayır kurumları yoluyla karşılanmıştır. Ancak hayır kurumları gelirleri arasında özellikle zekâtın yer alması, söz konusu kurumların harcama alanlarının sınırlarını tartışmalı hale getirmiştir. Zira

${ }^{41}$ Hacı Mehmet Günay, "Vakıf”, Türkiye Diyanet Vakfı İslam Ansiklopedisi (İstanbul: TDV Yayınları, 2012), 42/478, Abdullah b. Nâsır, Tevcîhu Mesârifi'l-vakf, 12.

42 Abdullah b. Nâsır, Tevcîhu Mesârifi'l-vakf, 17.

43 Ubeyr Katmani, “Müessesâtü'l-vakfiyye fi'l-Ahdi'l-Osmânî, el-İmâreu'l-âmiretu fî Beyti'lMakdis ve eseruhâ fi'l-hayeti'l-ictimâiyye", Mecelletu dirâseti Beyti'l-Makdis, 17/1 (2017), 75 . 
496 | A. CANER / Hayır Kurumlarının Gelirleri ve Bunların Sarf Yerleri

yukarıda da belirtildiği üzere hayır kurumlarının harcama alanları arasında ihtiyaç sahibi olan gerçek kişiler olduğu gibi hükmi kişiliğe sahip mescit, imaret, köprü, çeşme gibi yapılar da yer almaktadır. Bu sebeple hayır kurumları gelirlerinden zekât, sadaka, teberru ve hibe'nin harcama alanlarıyla ilgili değerlendirmelere kısaca değinmek yerinde olacaktır.

\subsection{Zekât}

Zekât, İslam'ın beş temel esasından biridir. Ayet ve hadislerde zekât kesin olarak emredilmiş, ${ }^{44}$ dinen zengin sayılan Müslümanların mallarının bir kısmını Allah rızası için belirlenen kişilere karşılıksız olarak vermeleri istenmiştir. Kur'an-ı Kerim'de zekâtın sekiz guruba verilebileceği yer almakla beraber sayılan guruplarla ilgili kullanılan kavramların yapısı ve bunlara yüklenen anlam çerçevesinde oluşan ihtilaf, zekâtın sarf alanı konusundaki görüş ayrılıklarının temelini oluşturmuştur. Örneğin zekâtın verileceği guruplardan biri için في سبيل الله ifadesi kullanılmıştır. Ulema في سبيل اله ifadesinin içeriğinden hareketle zekâtın sarf alanı ya da çerçevesi konusunda farklı görüşler ileri sürmüşlerdir.45 في سبيل الله ifadesinin kapsamılyla ilgili beş görüş öne çıkmıştır.

Birinci görüşe göre fîsebilillâh'tan kasıt, mücahitler ve sınır boylarını gözetleyen askerlerdir. Dolayısıyla zikredilen pay sadece onlara sarf edilir. Hanefî, Mâlikî, Şâfiî mezhepleri ve bir rivayete göre Ahmed b. Hanbel (öl. 241/855) bu görüşü benimsemiştir. ${ }^{46}$ Türkiye ve Suudi Arabistan'ın ilgili resmi kurumlarının yayınladıkları fetvanın da yine bu minvalde olduğu ifade edilmiştir. ${ }^{47}$

İkinci görüşe göre fîsebilillâh'tan kasıt, cihad ve hacdır. Çünkü hac da Allah yolunda cihad etmeye benzer. Dolayısıyla zikredilen pay, sadece cihad edenlere ve hacca gidenlere sarf edilir. Bunların dışındakilere sarf

44 el-Bakara 2/110; et-Tevbe 9/5.

45 Nihat Dalgın, "Zekât Hükümleri”, OMü İlahiyat Fakültesi Dergisi 16/16 (2004), 65-66.

46 Merğinânî, el-Hidâye, 1/110; Malik b. Enes b. Mâlik b. Âmir, el-Müdevvene (Beyrut: Dâru'l-kutubi'l-ilmiyye, 1994), 1/346; Harşî, Şerhu Muhtasar, 3/94; Şirâzî, Muhezzeb, 1/316; İbn Kudâme, el-Mŭgnî, 6/482.

47 Bk. Beytüllah Aktaş, Kur'an'a Göre Zekât'ın Harcama Kalemleri (İstanbul: İstanbul Üniversitesi, Sosyal Bilimler Enstitüsü, Doktora Tezi, 2013), 126-127; Hatice Erkoç, Yusufel-Karâdâvî'nin Fıkhu'z-Zekât Eseri Bağlamında "Fî Sebilillâh" Kavramı, Van İlahiyat Dergisi 8/13 (Aralık 2020), 205. 
A. CANER / Income of Charitable Foundations and Where to Use Them | 497 edilmez. Bu görüş, İbn Ömer (öl. 73/693) ve İbn Abbas'a (öl. 68/687) nisbet edilmiştir. Ayrıca Hanbelî mezhebi, İbn Teymiyye (öl. 728/1328) ve Hanefî mezhebinden Muhammed b. Hasan da bu görüşü desteklemiştir. ${ }^{48}$ Üçüncü görüşe göre Müslümanların genel maslahatı fisebilillah kapsamındadır. Dolayısıyla zikredilen pay, din ve devlet işlerinin bütünü için sarf edilebilir. Muassır âlimlerden Mahmut Şeltut (öl. 1893/1963), Muhammed Abduh (öl. 1849/1905) ve Seyyid Kutup (öl. 1906/1966) gibi âlimler bu görüşü savunmuştur. ${ }^{49}$

Dördüncü görüşe göre Allah'a yakınlık ve taati ifade eden her fiil, fisebilillah olarak kabul edilir. Buna göre zikredilen pay, mescit ve medreseleri bina etmek ve onarmak, ölülerin teçhiz ve tekfini gibi tüm hayır işleri için kullanılabilir. Bu görüşü savunanlar, Hanefî mezhebinden Kâsânî (öl. 587/1191), bazı Zeydiler ve İmamiye mezhebidir. ${ }^{50}$ Kâsânî, Bedâiu's-sanâi' adlı eserinde prensip olarak zikredilen sekiz sınıfın dışında

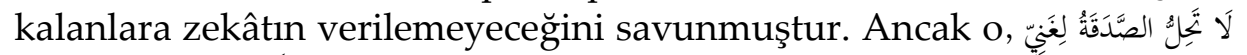

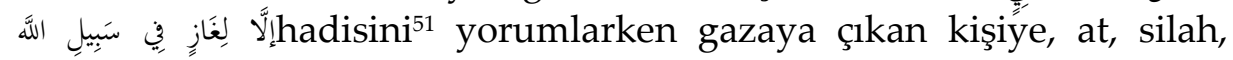
hizmetçi ve diğer ihtiyaçlar için zekât verilebileceğini ifade etmiştir. Gâzi olan kişinin zengin olup olmaması durumu değiştirmez. Çünkü gâzi, o anda zengin değil, ihtiyaç sahibi konumundadır. Nitekim ona göre aynı şey, "yolda kalanlar" ya da "borçlular" için de söz konusudur. Dolayısıyla o, mevzuyla ilgili görüşünü "Allah'a yakınlık ifade eden fiil”" ve "ihtiyaç" temelinde desteklemeye çalışmıştır.

Beşinci görüşe göre Âlimler, ilim talebeleri, müderrisler, kadılar ve müftüler fisebilillah grubuna dâhildir. O halde zikredilen pay, sayılan gruplara verilir. İbn Ẩbidîn (öl. 1307/1889), söz konusu görüşü Merğînânî (öl. 593/1197) ile San'ânî'ye (öl. 1182/1768) dayandırmaktadır. ${ }^{52}$

Muasır âlimlerden Karadâvî ise zekât ayetinin ilgili bölümünü şöyle yorumlamaktadır; "fisebilillah" ifadesi genel anlamda belli bir

48 İbn Kudâme, el-Mŭ̆nî, 6/482; Merğinânî, el-Hidâye, 1/110.

49 Reşîd Rızâ, Tefsîru'l-Kur'ani'l-Hakim (b.y.: el-Heyetu'l-Mısriyye, 1990), 10/432; Mahmud Şeltut, el-İslâm akidetun ve şerîatun (Kâhire: Dâru'ş-şurûk, 1968), 98; Seyyid Kutub, Fîzilâli'l-Kur'an (Beyrut: Dâru'ş-şurûk, 1412), 3/1658.

50 Kâsânî, Bedâiu's-senâi', 2/46.

51 Ebû Dâvûd, "zekât”, 24; İbn Mâce, "zekât”, 24.

52 Muhammed Emin b. Ömer b. Abdülaziz el-Hüseynî İbn Âbidîn, ed-Dımeşkî, Reddu'lMuhtâr ale'd-durri'l-Muhtâr (Beyrut: Dâru'l-fikr, 1992), 6/664. 
sayıya veya gruba hasredilemez ve âyetten bağımsız olarak zekâtın sarf yerleri için kullanılamaz. Zira söz konusu ifade, bir yönüyle umum ifade etmekte ve zikredilen gruplardan daha fazlasını kapsamaktadır. Bu açıdan bakıldığında sadece "fisebilillah" ifadesinden hareketle zekâtın sarf yerlerini sekiz sınıfa hasretmek âyetin zahirine de aykırıdır. Ancak lafız umum ifade etse de bu umum ifadeden has kastedilmiştir. O da cumhurun belirttiği gibi cihattır. Fakat günümüzde cihad kavramına yüklenen dar manadan farklı olarak sahabe ve tabiin dönemindeki geniş muhtevalı cihad anlayışı esas olmalıdır. ${ }^{53}$ Yani Karâdâvî̀ye göre doğrudan fîsebîlillâh ifadesinden hareketle zekâtın sarf alanları belirlenemez. Ancak bu kavramın işaret ettiği cihad ve onun muhtevasından hareketle zekâtın sarf alanları belirlenebilir. Dolayısıyla cihad; fikrî, ictimâî, iktisâdî, siyâsî ve askerî alanların tümünde yapılabildiğine göre zekât da sözü geçen alanların güçlenmesi için çalışan kişi ve kurumlara verilebilir.

Zekâtın sarf yerleriyle alakalı tartışmalar, ilgili kavramların muhtevası üzerinden yapıldığı gibi "temlik"in şart olup olmadığ hususunda da yapılmıştır. Bilindiği gibi temlik: zekât malının fakire doğrudan ya da vekâlet yoluyla teslim edilmesidir. ${ }^{54}$ Dolayısıyla temlik yoluyla zekât malı üzerindeki tasarruf yetkisi, onu alan kişiye geçmiş olmaktadır. Hanefi mezhebinin genel görüşüne göre zekât vecibesinin gerçekleşmesi için temlik şarttır. ${ }^{55}$ Diğer bir ifadeyle malın zimmetinin tahakkuk etmesi gerekir. Buna göre hükmî kişiliğe sahip olan hayır kurumları, diğer bir ifadeyle cami, okul, yol, çeşme ve benzeri yerler, zekâtın sarf alanı dışında kalmış olmaktadır. Çünkü buralara zekât verilmesi durumunda zimmet şartı gerçekleşemez. Diğer mezhepler de hayır kurumlarına doğrudan zekât verilemeyeceğini belirtmişlerdir. Fakat onlar meseleye temlik şartından ziyade sayılan guruplar arasında bu tür yerlerin olmadığına bakarak hüküm vermişlerdir. ${ }^{56}$

Belirtilen görüşler arasında cumhurun görüşünün isabetli olduğu açıktır. Fisebillillah ifadesinin umumundan hareketle zekâtın sarf yerleri

53 Yusuf el-Karadâvî, Fıkhu'z-zekât (Kahire: y.y., 1985), 2/625-526.

54 Abdullah b. Mahmud b. Mevdûd el-Mevsilî, el-İhtiyâr li ta'lîli'l-Muhtâr (Beyrut: Daru'lkutubi'l-ilmiyye, 1937), 2/50.

55 Serahsî, el-Mebsût, 2/202; İ̉n Abidîn, Reddü'l-Muhtâr, 2/344.

56 İbn Kudâme, el-Muğgn̂, 6/21. 
belirlenemez. Zira İslam'1 kabul eden herkes bir anlamda Allah yolundadır ve Allah'ın rızasına uygun ve ona yaklaşmak amaciyla yapılan her türlü iş de o kapsamda değerlendirilebilir. Hâlbuki nas tarafından gruplar tek tek belirtilmiştir. Bu da zekâtın bunların dışındakilere verilmeyeceğine işaret etmek içindir. Aksi takdirde zikredilen sınıfların bir anlamı olmayacaktır. Nitekim zekât gelirlerinden

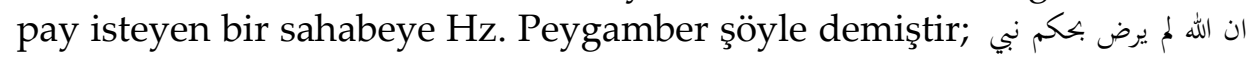
(Yüce Allah sadaka (zekât) lar hususunda ne Peygamberinin ne de bir başka şahsın söz söylemesine razı olmadı ve bizzat kendisi, zekâtların sekiz sinıfa verilebileceğine hükmetti. Şayet sen bunlardan isen, sana hakkını vereyim." 57 Burada "fisebîlillâh" kelimesinin anlamı yukarıda belirtildiği gibi "Allah yolunda olmak" veya "Allah'ın rızasına uygun ve ona yaklaşmak amacıyla yapılan her türlü iş" şeklinde olsaydı Hz. Peygamber'in bu sahabenin isteğini reddetmemesi gerekirdi. Çünkü o sahabe de Müslüman olması yönüyle Allah yolundadır. Ayrıca görüş sahipleri, fisebilillah ibaresinden hareketle zekâtın "cihad" edenlere sarf edileceği konusunda ittifak ederken diğer kişi ve yerlere de zekâtın verilip verilmeyeceği konusunda ihtilaf etmişlerdir. İttifak edilen görüşü, ihtilaf edilene tercih etmek ihtiyata daha uygundur.

\subsection{Sadaka}

Hayır işlerinin görülmesi ve geliştirilmesinin önemi bakımından sadaka, zekattan sonra ikinci sırada yer alır. İslam, ictimai dayanışmanın gereği olarak bazı araçları meşru görmüştür. Gönüllülük temelinde meşru görülen ve hatta teşvik edilen bu araçların başında sadaka yer alır. Âlimler sadakayı, Allah'a kurbet ifade etmek için hayatta iken karşılıksız temlik etmek ya da kendisiyle Allah katında sevap umulan atiyye olarak tanımlamışlardır. ${ }^{58}$ Râğıb el-İsfahânî (öl. 400/1010) ise onu şöyle tanımlamıştır; Allah'a yakınlık kurmak için insanın malından çıkardığı (verdiği) şeydir. ${ }^{59} \mathrm{Bu}$ yönüyle sadaka, zekâta benzemektedir. Ancak, sadakada zorunluluk değil, gönüllülük esastır. Zekâtta ise vücubiyyet

57 Ebu Davud, "Zekât", 23.

58 Said b. Ali b. Vehf el-Kathânî, Sadakatü't-tatavvu' fi'l-İslâm (Riyad: Silsiletü'l-zakâti'1Muhsin, 1426), 5.

59 Hüseyin b. Muhammed Râğıb el-İsfahânî, el-Müfredât fî Ğarîbi'l-Kurân (b.y.: Dâru'1kalem, 1412), "Sdk", 1/480. 
vardır. Zekât veren kişi içinden gelerek Allah'a bağlılığını ifade emek için bu fiili gerçekleştirirse verdiği şey sadaka olarak da isimlendirilebilir.

Allah'ın rızasını kazanmak amacıyla kişinin kendi malından harcama yapması, muhtaçlara ayni ve nakdi yardımda bulunması manasına gelen infak kavramı hem zekât hem de sadakayı kapsayacak şekilde kullanılmıştır. ${ }^{60}$ Naslarda infak kavramına geniş bir şekilde yer verilmiş, müminlerin başlıca vasıfları sayılırken iman ve namazdan sonra infak zikredilmiştir. ${ }^{61}$ Dolayısıyla inanan insanların mallarından infakta bulunmaları teşvik edilmiştir.

Gönüllülük esasına bağlı olarak verilen sadakalar, süreklilik arz etmeyen gelirlerindendir. Bu gelirlerin sarf yerleriyle ilgili sorumluluk öncelikle hayır kurumlarına aittir. Kefâret ve nezir sonucunda ödenen cezalar ile deprem, yangın, doğal felaket ve musibetler akabinde Allah'ın rızasını kazanmak amacıyla insanların maruz kaldıkları sıkıntılara ortak olmak ve acılarını hafifletmek için verilen her türlü aynî ve nakdî yardımlar da sadaka olarak kabul edilmiştir. ${ }^{22}$ Burada şu hususun vurgulanması gerekir. Zekâtın doğrudan hayır kurumlarına verilmesi temlik şartı nedeniyle problem teşkil etse de tatavvu sadakası için bu durum sorun oluşturmaz. Çünkü tatavvu sadakasında böyle bir şart yoktur. Ancak yukarıda da geçtiği üzere tatavvu sadakası emanet hükmünde olduğundan onun sarfıyla ilgili, sahibinin izin ve rızası ile öncelikli sarf yerleri belirleyici olacaktır.

\subsection{Hibe ve Teberru}

Hibe, hukuk dilinde bir malın karşılıksız olarak başkasına temlikini ifade eden akdin adı olarak kullanılmıştır. ${ }^{33}$ Teberru ise kişinin yükümlü olmadığ 1 bir şeyi karşılıksız vermesi ${ }^{64}$ şeklinde ifade edilmiştir. Hibe, teberru, tatavvu, sadaka, hediye ve bağış kavramları arasında bazı farklar olsa da bunların yakın anlamlı lafızlar olduğu belirtilmiştir.

60 Mustafa Çağırıcı, "İnfak”, Türkiye Diyanet Vakfı İslam Ansiklopedisi (İstanbul: TDV Yayınlar1, 2000), 22/289-290.

61 Bk. el-Bakara 2/2.

62 Said b. Ali, Sadakatu't-tatavou', 70.

63 Ali Bardakoğlu, "Hibe", Türkiye Diyanet Vakfi İslam Ansiklopedisi (İstanbul: TDV Yayınları, 1998), 17/421.

64 Bilal Aybakan, "Teberru", Türkiye Diyanet Vakfi İslam Ansiklopedisi (İstanbul: TDV Yayınlar1, 2011), 40/215. 
Kur'an ve Sünnette teberru ve hibeyi çağrıştıran çokça ifade kullanılmış, insanların varlıklarının bir kısmını Allah rızası için bağışlamaları istenmiştir. ${ }^{65}$ İnanan insanlar da nasların bu çağrılarına kulak vererek, Allah'ın kendilerine verdiği malların bir kısmını ya da bütününü kişi ve toplumun yararına olacak şekilde hibe veya teberru yoluyla hayır kurumlarına bağışlamışlardır.

\section{Hayır Kurumları Gelirlerinin Öncelikli Sarf Yerleri}

Hayır kurumu gelirlerinin doğru şekilde sarf edilebilmesi o kurumun devamlılığı ve meşruiyeti bakımından oldukça önemlidir. Bu da ancak sağlam kriterlerin ortaya konulmasiyla mümkün olabilmektedir. Zira kişinin; dînî, dünyevî, mâlî, bedenî, maddi, manevi ihtiyaçları bulunabilir. Dolayısıyla bu ihtiyaçlara göre öncelikler belirlenmelidir. Maddi bakımdan ihtiyaç sahibi olanlar da kendi aralarında farklılık gösterebilir. Yeme, içme giyinme ve barınma gibi temel ihtiyaçlarını karşılamada zorlananlar olduğu gibi yokluğu sebebiyle hayatı zorlaştıran ancak yeme, içme mesabesinde olmayan ihtiyaçlar da vardır. Bu anlamda zaruri ihtiyaçlar varken hâcî olanlar, hâcî olanlar varken tahsînît6 ihtiyaçlar karşılanamaz. İşte hayır kurumlarının görevi, öncelikleri belirlemek ve bu önceliklere göre ihtiyaç sahibi olan kişi ve kuruluşlara yardım elini uzatmaktır. Şu bir gerçek ki zekât, sadaka ve hayır kuruluşlarının gelirlerinden faydalananların belli bir kısmı sağlıklı olup çalışabilir durumda olan kişilerdir. Bu durumda olanlara hayır kurumu gelirlerinden verip onları tembelliğe alıştırmaktansa onları çalışmaya ve bir meslek sahibi olmaya yönlendirmek daha isabetli görülmüştür. Nitekim Hz. Peygamber de her yardım dileyene zekât gelirlerinden vermemiş, onların bir kısmını kendi emeğiyle kazanmaya teşvik etmiştir. ${ }^{67}$ Günümüz şartlarında çalışabilir halde olup tembellikten

65 Bk. Âl-i İmrân 3/8; el-En‘âm 6/84; Meryem 19/49-50; eş-Şûrâ 42/49.

66 Zarûriyat; Din can, akıl, nesil ve malın korunmasına yönelik maslahatları içeren ihtiyaçlardır. Hâcîyat; Hayatın normal işleyişi için lazım olan maslahatlardır. Tahsiniyat; Zaruri ve hâcî grubunda yer almayan ancak hayatı kolaylaştıran maslahatlara denir. Bk. H. Yunus Apaydın, İslam Hukuk Usulü (Kayseri: Kimlik Yayınları, 2016), 122-123.

67 Hz. Peygamberin insanları kendi emeğiyle kazanmaya teşvik etmesiyle ilgili çokça rivayet aktarılmıştır. Onlardan biri şöyledir: "Herhangi birinizin iplerini alıp dağa gitmesi ve sırtına bir bağ odun yükleyip getirerek onu satması ve Allah'ın bu sebeple onun şerefini muhafaza etmesi, verip vermeyecekleri beli olmayan insanlardan bir 
dolayı dilenen kişileri, dilenmekten vazgeçirmek ve çalışmaya teşvik etmek için birçok vasıta kullanmak mümkündür. Özellikle bu konuda fert ve toplumu bilinçlendirmek hayır kurumlarının öncelikleri arasında yer almalıdır. Âlimler, vacip mesabesinde olan ihtiyaçlar varken mendup ve mübah mesabesinde olanlara öncelik verilemez demişlerdir. Buna göre açlıktan ölmek derecesine gelenleri doyurmak, felaketlere maruz kalanlara yardım elini uzatmak, hastalıkla boğuşanların tedavisine öncelik vermek, evsizlere barınaklar temin etmek, yetimlerin başını okşamak ve sahip çıkmak, yaşlılara ve dul kadınlara bakmak, engellileri gözetmek, dini inançlarından dolayı saldırıya maruz kaldığı için yiyecek, içecek, giyim ve eğitim imkânları gibi temel ihtiyaçlarını karşılamada zorlananlara yardım etmek öncelikli ihtiyaçlardan bazılarıdır. Bunlar aciliyet gerektirirken sünnet ve nafile mesabesinde olan tekrarlı hac ve umre turlarını düzenlemek, itikâfa girenlere ikram etmek, Ramazan ayında iftar sofralarını kurmak, şerbet ve misvak gibi şeyleri dağıtmak, hayrı yerinde kullanmamak demektir. İbn Mesud'un konuyla ilgili şu sözleri dikkat çekicidir; Ahir zamanda farz olmadı̆̆ı halde hacılar çoğalır, yollarda yaptıklarn ticaretle hac işi onlara kolay gelir ve kazançları artar. Sevaptan mahrum bir şekilde geri dönerler. Çölde binitleri onları dolaştırır da yanı başlarında bulunan komşularının hallerini sormazlar. 68

Hayır kurumları, süreklilik gerektiren iş ve ortamların oluşmasına katkıda bulunanlara yardımı öncelemelidir. Diğer bir ifadeyle daimi hayır müesseselerinin açılmasına yardım etmeli ve bu vesileyle ihtiyaç sahiplerinin ihtiyacını gidermeye çalışmalıdır. Nitekim Hz. Peygamber, "Amellerin en hayırlısı az da olsa sürekli olanıdır" buyurmuştur. Dolayısıyla fakirler yararına fabrika, atölye, fırın, lokanta gibi yerler açıp oralarda belli bir ücret karşıllı̆ı̆nda çalışabilecek durumda olan fakir, dul vb. kişileri çalıştırarak hem onlara sürekli bir iş imkânı sağlanmış olur hem de oralardan elde edilen gelirlerle daha fazla kişinin ihtiyacı karşılanmış olur.

Hayır kurumları, kişinin kendisiyle sınırlı kalmayıp başkalarına da sirayet edebilen yardım çeşitlerini öncelemelidir. Zira Hz. Peygamber:

şeyler dilenmesinden çok daha hayırlıdır. Buhârî, "Zekât”, 50; Nesâî, "Zekât", 85; İbn Mâce, "Zekât", 25.

68 Ebû Hâmid Muhammed b. Muhammed b. Muhammed b. Ahmed el-Gazzâlî, İhyâu ulûmiddîn (Beyrut: Dâru'l-ma'rife, ts.), 3/409. 
"Allah katında insanların en sevimlisi insanlara en faydalı olandır. Allah'ın en çok sevdiği amel bir Müslümana verdiğin mutluluktur veya ondan bir derdi gidermen, borcunu ödemen, açlığını doyurmandır. Bir kardeşimin işini görmek için onunla beraber yürümem, mescitte bir ay itikâfa girmemden daha sevimlidir" 69 buyurmuştur. Hadisten de anlaşıldığı üzere en hayırlı amel, kişinin kendisiyle sınırlı kalmayıp diğer insanlara da faydası dokunan ameldir. Çünkü yapılan iyilikten başkaları istifade ettiği oranda toplum gelişecek ve güçlenecek, aralarındaki bağlar artacak ve ilerleyecektir. Bu manada Allah'ın dinine davet edenlere yardım etmek, Kur'an öğretimi için ortam hazırlamak ve zorda kalan kimselerin borçlarını ödemek en hayırlı amellerden kabul edilmiştir.

Hayır kurumları günübirlik ve geçici ihtiyaçları karşılamaktan ziyade daimi ve sürekli ihtiyaçları gidermeye yönelik yardım çalışmalarını öncelemelidir. Zira bu tür çalışmalar sadaka-i câriye hükmünde olduğundan hayrı yapan kişinin ölümünden sonra da amel defteri müsbet manada işlemeye devam edecektir. Nitekim İslam tarihi boyunca faaliyet gösteren hayrî vakıflar bu amacı gerçekleştirmek üzere kurulmuşlardır.

\section{Hayır Kurumlarının Alım Satımla İlgili Tasarruf Yetkileri}

Mal, insanı hayata bağlayan ve çalışmaya sevk eden ana faktörlerden ve hayır kurumlarının da temel unsurlarındandır. Mal, aynı zamanda hayır kurumlarının ve orada çalışanların mali güvencesi olduğu gibi o kurumlara tevdi edilmiş bir emanettir. Dolayısıyla oralardaki mali disiplin o kurumların gücünü ve güvenirliğini gösteren önemli bir gösterge olarak kabul edilir. Bu sebeple hayır müesseselerinde malın biriktirilmesi, yatırım amaçlı kullanılması ve sarf yerleri konusunda dikkatli olunması gerekir. Bu da ancak emanete riayet etmekle ve tevdi edilen emaneti şer'i amacı dışında kullanmamakla mümkün olmaktadır. Bu manada hayır kurumlarının teberru edilen aynî ve nakdî yardımların alım ve satımla ilgili hususları, borç verme şekilleri, ihtiyaç anında ahz-1 vekilin sadakalardan yararlanıp yararlanmayacağı ve günümüz vakıf harcamalarının nerelere yapılacağı ile ilgili yetkileri tartışılmıştır. Fıkıh eserlerinde "Hayır kurumlarının alım satım ile ilgili tasarrufu" şeklinde doğrudan bir bölüm yer almamaktadır. Ancak söz konusu eserlerde bu

${ }^{69}$ Ebû'l-Kâsım Süleyman b. Ahmed b. Eyyûb et-Taberânî, Mu'cemu's-sağî̀r (Beyrut: Dâru İmâr, 1985), 2/106. 
mevzuya benzer konular işlenmiştir. $\mathrm{O}$ da vekilin yetkili olmadı̆̆ 1 alanlardaki tasarrufudur. Dolayısıyla burada konu önce bu çerçevede incelenecek sonra hayır kurumlarıyla bağlantısı kurulmaya çalışılacaktır.

\subsection{Hayır Kurumlarına Verilen Yetkinin Aşılması}

Bir kimsenin birine kendi adına hukuki işlem yapma yetkisini vermesi olarak tanımlanan vekâlet, bünyesinde belli unsurları ve şartları taşıyan iki taraflı hukukî bir muamele olarak ifade edilmiştir. ${ }^{70}$ Kendisine iş tevdi edilen tarafa vekîl, işin sahibine ise müvekkil denmiştir. Buna göre vekil konumunda olan hayır kurumunun kendisine verilen yetkiyi aşması durumunda vekâletinin düşüp düşmeyeceğiyle ilgili iki görüş öne çıkmıştır. Ağırlıklı görüşe göre vekâlet düşmez. Çünkü vekil, bünyesinde iki özellik bulundurur. Birisi müvekkilin güvenirliliği, diğeri de müvekkil adına tasarrufta bulunma yetkisidir. Vekil, yetkisini aşmadığı sürece müvekkil adına tasarrufta bulunur ve bu tasarrufu da geçerlidir. Yetki aşımında ise güvenirlilik gider fakat vekâlet baki kalır. ${ }^{71}$ Daha az tercih edilen görüşe göre vekâlet düşer diğer bir ifadeyle fasit olur. Bu görüşü savunanlara göre güvenirlilik ve tasarruf yetkisi birbirini gerektiren iki özelliktir. Onlardan birinin gitmesiyle diğeri de gider. Vekil tarafından yapılan tasarruf da, müvekkil onay verirse geçerli, vermezse vekil adına geçerli olsa da müvekkil adına geçersiz bir işlem olur. Dolayısıyla vekil, vekâlet yoluyla müvekkilinin bilgisi ve izni olmadan meşru olmayan bir şekilde onun malında tasarrufta bulunması gayr-i ahlaki olduğu gibi meşru da değildir.

Hayır kurumlarını işletenler vekil sıfatıyla bu işleri yapmaktadır. O halde vekâlet için söz konusu olan durumlar, hayır kurumlarını işletenler için de aynen geçerlidir. Dolayısıyla müessese yetkilileri, hayır sahiplerinin bilgisi ve izni olmadan bir tasarrufta bulunamazlar. Şayet hayır sahiplerinin mevzuyla ilgili bir şartı varsa ve bu şart da meşru ise ona göre tasarrufta bulunmak gerekir. Şarta muhalif hareket edilemez. Herhangi bir şart koşulmamışsa bu durumda maslahata göre tasarrufta bulunmak icap eder. Hayır müesseselerindeki malların tasarrufuyla ilgili kişilerin tercihi değil, dini öğretilerin gerektirdiği şekilde hareket etmek zorunludur ve bu konudaki duyarlılık esas alınmalıdır. Ta ki kendilerine emanet edilen malın infakı konusunda şer'î kurallara riayet edilebilsin.

70 İbn Manzûr, Lisânü'l-Arab, “vkl”, 11/736.

${ }^{71}$ Serahsî, el-Mebsût, 14/65. 
Buradan hareketle şöyle denebilir: Kişi bir binayı hastane olmak şartıyla hayır kurumlarına bağışlasa (vakfetse), bağışlayanın izni ve rızası olmadan söz konusu bina başka bir amaçla kullanılamaz. Ancak bağış, genel olup herhangi bir kayıt konulmamısssa bu durumda toplumun maslahatı esas alınarak umumum faydasına olacak şekilde kullanılabilir.72 Aynı şekilde Müslüman bir beldenin yararına kullanılmak üzere yardımsever insanlar tarafından toplanan para ya da malların tasarrufu için özel bir şart konmamışsa, teberru amacına uygun olarak o beldedeki fakirlerin ihtiyaçları veya oradaki çocukların dini eğitimi için sarf edilebilir. Ancak yetim veya fakirler belirlenmişse sadece o belirlenenlere verilir.

Aynî yardımların tasarrufu ile ilgili durum genel anlamda nakdî yardımların tasarrufu gibi değerlendirilmiştir. ${ }^{73}$ Yani aynî yardımların amacı dışında kullanılması ya da satılması temelde caiz görülmemiştir. Şu var ki aynî yardımlar zaman içerisinde yıpranıp tahrip olabilir. Dolayısıyla asıl amaç olan yarar sağlama fonksiyonlarını kaybedebilirler. Böyle durumlarda onların satışıla daha fazla maslahat sağlanacaksa teberruda bulunanın beyanına muhalif olsa dahi aynî malın satılabileceği belirtilmiştir. Çünkü aynî malın satışında teberruda bulunan kişinin sözüne zahiren muhalefet edilmiş olsa da gerçekte hem onun hem de lehine teberruda bulunulanlar için maslahat söz konusudur. Şurası bir gerçek ki bazen insanlar aynî yardımlardan ziyade nakdî yardıma ihtiyaç duyabilirler. Tersi de söz konusu olabilir. O halde hayır kurumları temelde maslahatı, maslahatta da evleviyet prensibini esas alarak tasarrufta bulunmalıdırlar. Aynî yardımları sebepsiz yere satmak ya da tüketmek ise ittifakla haram kabul edilmiştir. ${ }^{74}$

Hülasa olarak şu söylenebilir: Vekil, güvenilirliği sayesinde bu görevi üstlenmiştir. Dolayısıyla güvenirliğinin gereği olarak müvekkilin sözüne göre hareket etmesi gerekir. Bununla beraber malı ya da aynı elinde bulunduran hayır kurumlarının uygulamalarına bakıldığında zaman zaman buna uyulmadığı, hatta müvekkilin sözüne aykırı bazı

72 Kâsânî, Bedâiu's-senâi', 6/218.

73 Ahmet Akgündüz, "İslâm Hukukuna Göre Vakıf Mallarının Mülkiyet Meselesi”, Bakanlarda Osmanlı Vakıfları ve Eserleri Uluslararası Sempozyumu (Ankara: Vakıflar Genel Müdürlüğü Yayınları, 2012), 28-29.

74 Akgündüz, İslâm Hukukuna Göre Vakıf Mallarmın Mülkiyet Meselesi, 28. 
tasarruflarda bulundukları görülmektedir. Âlimler şu iki şart dâhilinde teberruda bulanın sözüne aykırı tasarrufların geçerli olabileceğine hükmetmişlerdir. Birinci şart; hayır müesseseleri maslahatın ve ihtiyacın hangi alanda yoğunlaştığını teberruda bulunandan daha fazla bilmeleri gerekir. İkincisi; Hayır müessesesinin yapılan bu değişikliği gerekçesiyle birlikte teberru sahiplerine bildirmesi gerekir. Aksi takdirde emanete ihanet etmiş olurlar. ${ }^{75}$

\subsection{Hayır Müesseselerinden Borç Alma}

Hayır kurumları gelirlerinin ağırlıklı olarak zekat ve sadakalardan oluştuğu ve zekâtın sarf yerlerinin bizzat nas tarafından belirlendiği daha önce ifade edilmişti. Ancak âlimler, zekâtın sarfıyla ilgili nas tarafından belirlenen sekiz sınıf hususunda temlik şartının olup olmadığını tartışmışlardır. Bazı âlimler böyle bir şartın olmadığını ileri sürseler de çoğunluk temlik'in şart olduğu görüşünü benimsemiştir. ${ }^{76}$ Bilindiği üzere temlik, bir malın aynına veya menfaatine yönelik mülkiyeti aktarma ya da şer'î açıdan akar üzerinde tasarruf edebilme yetkisidir. ${ }^{77}$ Burada zekâtın temlikinden amaç, fakir ve benzer durumda olanlara bir malı kendi hür iradeleriyle üzerinde tasarruf edecek şekilde vermektir. Temlik'i şart koşanlar zekâtın sekiz sınıfa verileceğini belirten âyeti delil olarak öne sürmektedirler. Onlara göre âyetin başında yer alan hasr bildirir. Dolayısıyla zekât, sadece belirtilen sekiz sınıfa verilir للفقراء ifadesinin başındaki $J$ takısı da temlik'e delalet eder, sayılan diğer sınıflar ise lafzına atfedilmiştir. Dolayısıyla bunlar zekâtın sarf yerleriyle ilgili sadece "mübah olma" özelliğini yetersiz görmektedirler. Mübah olma ile beraber temlikin de şart olduğunu ileri sürmektedirler. Diğer bir ifadeyle sarfın mübah olduğu kişi ve yerlere zekât da verilebilir anlayışını kabul etmemektedirler. Ayrıca naslarda zekâtın verilmesiyle ilgili الايتاء lafzı geçmektedir. Bilindiği gibi الايتاء lafzı الايطاء manasındadır. O da temlik

75 Diâ Adil, el-Müessesâtü'l-hayriyye, 128.

76 Murtaza Köse, "Fî Sebîlillâh" Kavramının Zekât Açısından Tahlili", Atatürk Üniversitesi İlahiyat Fakültesi Dergisi 21(2004), 127-128.

77 Bk. Ebû'l-Abbâs Takiyuddîn Ahmed b. Abdulhalim b. Mecdiddîn b. Abdisselâm elHarrânî, el-Kevâidu'n-nurâniyye el-fikhiyye (Memleketu'l-Arabiyyetu's-Suudiyye: Dâru İbnu'l-Cevzî, 1402), 300; Bilal Aybakan, "Temlik", Türkiye Diyanet Vakfi İslâm Ansiklopedisi (İstanbul TDV Yayınları, 2011), 40/428. 
manasında "vermek" demektir. Buna göre zekâtın verilebilmesi için fakirin bizzat kabzetmesi ve onu temlik etmesi gerekir. ${ }^{78}$

Bu görüşe şöyle itiraz edilmiştir: Âyette zikredilen للفقراء lafzının başındaki I takısı sadece temlik manasını içermez. Temlikle beraber beyan, ihtisas, akıbet gibi farklı manaları da ihtiva eder. Burada temlikten ziyade ihtisas için kullanılmıştır. Zira âyetin siyakından bunu anlamak mümkündür. Nitekim âyet münafıkların sadakaya ehil olmadıklarına dikkat çekerek onları zemmetmekte ve akabinde "sadaka ancak fakirlere verilir..." diyerek sadakanın başkalarının değil fakirlerin hakkı olduğunu vurgulamıştır. Aynı şekilde الايتاء lafzı sadece temliki değil, onunla beraber, mübah kılma manasını da ihtiva etmektedir. Nitekim Hz. Peygamber, kendisine getirilen yiyecekler konusunda "Bunlar hediye mi sadaka mı?" diye sormuş, onların sadaka olduğunu öğrenince "Siz yiyiniz. Ben yemem"79 buyurarak orada bulunan (zengin-fakir) herkese sadaka yemeğini mübah kılmıştır. Dolayısıyla sadece fakirlere temlik ettirmemiştir. Bu da الايتاء kelimesinin mübah kılma manasını da içerdiğini ortaya koymaktadır. ${ }^{80}$

Söz konusu kelimenin mübah kılma manasını da içerdiğiyle ilgili ileri sürülen bu rivayet, delil olma yönüyle zayıf gözükmektedir. Zira rivayette ikram edilen sadaka yemeği, farz olan sadakayı yani zekâtı değil, gönüllülük esasına bağlı olan tatavvu sadakasını ifade etmektedir. Farz olan sadaka olsaydi sadece oradaki fakirlerin ondan yemesi gerekirdi. Oysaki hazır olan bütün sahabeler ondan yemiştir. Buradan da çoğunluğun görüşünün daha isabetli olduğu ortaya çıkmaktadır.

Zekâtın sarf yerleri konusunda temlik şartını savunanlara göre karz-1 hasen şeklinde olsa dahi zekâttan borç verilemez. Aksi takdirde nassın belirlediği grupların dışında bir yere sarf edilmiş olur ki o da caiz değildir. Ayrıca borç vermede temlik şartı gerçekleşemez. Çünkü borç

78 Bk. Kemâleddîn Muhammed b. Abdulvâhid b. Abdülhamîd es-Sivâsî, Fethu'l-kadîr, (Beyrut: Dâru'l-fikr, ts.), 2/270; Maverdi, el-Hâvi'l-kebîr, 3/170; İbn Kudâme, el-Muğni, 10/10.

79 Buhari, "Hibe", 5.

80 Ebû Abdillâh Muhammed b. Ali b. Muhammed eş-Şevkânî, es-Seylu'l-cirâr elmütedeffak alâ hadâiki'l-ezhâr (b.y.: Dâru İbn Hazm, ts.), 695. 
şeklinde verilen zekât malı zekât fonu ile borçlu arasında sürekli el değiştirip duracak ve gerçek sahibinin eline ulaşamayabilecektir. ${ }^{81}$

Malum olduğu üzere zekât vermekle yükümlü olanlar, ya zekât malını doğrudan sahiplerine verecek ya vekâlet aracılığıyla ya da konuyla ilgili yetkili birine verip onun aracılığıyla sahiplerine ulaştıracaklardır. Yetkili veya vekil olanlar, zekât malını ancak sahiplerine ulaştırmak üzere zimmetlerinde bulundurur, başka şekilde bulunduramazlar. Zekât malı zekât fonu ve borçlu arasında dönüp dolaşırsa asıl sahiplerine ulaşamamış olacaktır. Hâlbuki zekât malının geciktirilmesi bile tasvip edilemezken onlarda süreklilik arz edecek şekilde kalmasının caiz görülmesi düşünülemez.

Muasır âlimlerden Muhammed Ebû Zehre (öl. 1898/1974) ve Abdülvehhâb Hallâf (öl. 1888/1956) gibi bazı âlimler, kıyas yoluyla zekât malından borç verilebileceğine hükmetmişlerdir. ${ }^{82}$ Onlara göre nasla belirtilen sekiz gruptan biri olan ğârimin/borçlulara zekât verilebileceğine göre borç almak isteyenlere de zekât malından verilebilir. Bu görüşe göre zekâtın sarf yerlerinden borçlulara verilen pay esas alınarak bir fon oluşturulabilir ve buraya bir miktar zekât malı aktarılabilir. Bu fondan da zorda kalıp borç almak isteyenlere karz-ı hasen şeklinde borç verilebilir. Böylece onları faiz illetinden uzak tutmak için alternatif meşru bir imkân sunulmuş olur. Ancak Karadâvî, onların bu görüşünü eleştirmekte ve yapılan kıyasın da isabetli olmadığını ifade etmektedir. Ona göre nasla belirtilen borçlular, bilfiil borca batmış ve ondan kurtulmak isteyip de çaresiz kalan kimselerdir. Fakat kredi almak isteyenler gerçek borçlu değildir ki aynı sınıfa dâhil olsunlar. Dolayısıyla illet birliği olmadığından onlara zekât malından pay ayrılamaz ve bu paydan borç verilemez. ${ }^{83}$

Burada şu söylenebilir: borç almak isteyen kişi, işini genişletmek, daha büyük yatırımlar yapabilmek için borçlanacaksa böylelerine zekât malından borç vermek doğru olmaz. Çünkü zekât temelde fakirlerin hakkıdır. Bu durumda olanlar ise fakir değil, zengin sayılırlar. Borç almak isteyen kişi fakir ise zaten zekât onun hakkıdır. İhtiyacının bir kısmı ya da tamamı zekât fonundan karşılanabilir. Fakir olmadığı halde işini genişletmek için borç isteyen kişilere ise ihtiyaç duyduğu miktar kadar

\footnotetext{
81 Yusuf el-Karadâvî, Fıkhu'z -zekât (Kahire: y.y., 1985), 2/634.

82 Yusuf el-Karadâvî, Fıkhu'z-zekât, 2/634.

83 Yusuf el-Karadâvî, Fıkhu'z-zekât, 2/634.
} 
başka fonlardan karz-1 hasen şeklinde borç verilebilir. Durumuna bakılmaksızın ihtiyacının olduğunu söyleyen kişilere zekât malından verip daha sonra onlardan tekrar almak zekâtın asıl sahiplerine ulaşmasını engellediği ya da geciktirdiği için mahzurlu görünmektedir.

Gönüllülük esasına bağlı olan sadaka mallarından borç verme konusunda ise hayır kurumları emanetçi konumundadır. Sadaka malları onların değildir ki istedikleri gibi tasarruf edebilsinler. Dolayısıyla sadakayı verenlerin izni ve rızası olmadan borç veremezler.

\section{Günümüzde Hayır Kurumları Gelirlerinin Sarf Yerleri}

Günümüzde hızlı nüfus artışı ve teknolojik gelişmelere bağlı olarak hayır kurumu gelirlerinin de sarf alanları genişlemiştir. Şüphesiz her gelişme beraberinde bir külfet getirecektir. Bu külfetlere bağlı olarak, yeni hazırlıklar ve değerlendirmeler de kaçınılmazdır. Şu bir gerçek ki hayır kurumlarının ve o kurumlara katkı sağlayanların temel amacı iyilik yapmak ve bunun sonucunda Allah'ın rizasını kazanmaktır. Bu manada iyiliğin din ve dünyaya bakan yönüyle birçok çeşidi bulunmakta ve insanların ihtiyacına göre de farklılık arz etmektedir. Örneğin eskiden bir ihtiyaç görülmeyip masraf gerektirmeyen dini kitapların basımı ve neşri günümüzde hayır kurumlarının önemli meşguliyet alanlarından biri haline gelmiştir. Burada mevzumuz açısından önemli olan husus, hayır kurumlarında biriken zekât, sadaka, hibe ve teberrudan oluşan fonlarla bu tür alanların desteklenip desteklenemeyeceğidir. Yukarıda serdedilen görüşler doğrultusunda şu söylenebilir: Muayyen şartlarla tahsis edilmemiş sadaka, hibe ve teberru fonlariyla maslahat temelinde ve önceliklerin belirlenmesi koşuluyla birçok faaliyet, hayır kurumları aracılığıyla desteklenebilir. Zekât için aynı şeyi söylemek zordur. Zira doğrudan nas tarafından zekâtın sarf alanlarının belirlenmesi ve bazı ulema tarafından temlik'in şart koşulması onun sarf alanını daraltmış olmaktadır. Fakat temlik şartı göz önünde bulundurulmayıp fîsebîlillâh kavramından kastedilenin cihâd olduğu ve bu kavramın da geniş manası referans alınacak olursa zekâtın sarf alanı genişlemiş olacaktır. Buna göre günümüz hayır kurumları gelirlerinin sarf alanları şu şekilde belirlenebilir:

1. Kitle iletişim araçları: Herhangi bir olay ya da problem konusunda doğru ve sağlıklı bir şekilde bilgilendirme yaparak insanların konu hakkında isabetli görüş bildirmelerine katkı sunan araçlara kitle 
iletişim araçları denir. Bu araçlarla insanları kendi dinleri hakkında bilgi sahibi yapmak, şüpheleri gidermek, İslam'ın hakikatini izhar edip insanları ona davet etmek ve Hz. Peygamber'in mesajını iletmek mümkün olabilecektir. Özellikle İslami kitle iletişim araçları, İslam toplumuna hitap edecek fert ve aileye fayda sağlayacak alternatifleri hedeflemelidir. Nihayetinde bu da iyilik kapsamında değerlendirilmesi gereken bir mevzudur. Dolayısıyla hayır müesseseleri bu manada kitle iletişim araçlarını destekleyebilir ve bunun için fon ayırabilir. Nitekim birçok İslam ülkesinde hayır kurumlarının desteklediği görsel ve yazılı yayın faaliyetleri bulunmaktadır. Ayrıca hayır kurumlarının birçok süreli ya da süresiz şerî̀ yayını doğrudan kurduğu da görülmektedir. Kitapların basım ve dağıtım görevini de bu kapsamda değerlendirmek gerekir. Eskiden beri var olan bu hizmet, günümüzde daha kompleks bir yapı arz etmektedir. İlmi eserlerin neşri ve tevzii kolaylaşsa da araç gereçlerin alımı ve bakımı masraf gerektirmektedir. Hayır kurumları, yazılan bazı eserlerin basım ve dağıtım masraflarını üstlenmektedir. Toplumun maslahatı böyle bir harcamayı gerekli kılmaktadır.

2. İş yerleri açmak: Günümüzde hayır kurumları, âtıl olanlar veya çalışacak alan bulamadığı için boşta kalanlar için iş fırsatlarını sunmakta ve onları meslek sahibi yapıp topluma kazandırmaktadır. Şüphesiz böyle bir sarf kalemi, hayır kurumlarının kuruluş amacına uygun ve toplumun maslahatı için de gerekli bir durumdur.

3. İmam ve müezzinler için lojman yapmak: Günümüz hayır kurumları gelirlerinin sarf alanlarından biri de din görevlilerinin iskânı için cami ya da Kur' an kurslarının arsası üzerine lojman adı altında evler inşa etmektir. Böylece din görevlilerinin ibadethaneye veya kursa yakınlığı sağlanarak verimlilikleri artmış olacaktır. Özellikle Türkiye ve Suudi Arabistan gibi bazı ülkelerde bu uygulama yaygın olarak kullanılmaktadır. Bu, hayır kurumlarının kuruluş ve işleyiş amaçları kapsamında değerlendirilebilecek bir mevzudur.

4. Ağır hastalıklara maruz kalanların tedavisini üstlenmek: Eskiden beri bu tür yardımlar iyiliğin bir çeşidi olarak kabul edilmiştir. Ancak günümüzde durum daha ciddi olarak ele alınmakta, çeşitli dernekler adı altında bağışlar toplanıp yardım eli uzatılmaktadır.

5. İftar çadırları kurmak: Ramazanlarda oruç tutanlara iftar sofralarını kurmak hayır kurumu gelirlerinin önemli sarf alanlarından 
biridir. Özellikle ülkemizde varlıklı kişilerin belediyeler ya da dernekler aracılığıyla yaptıkları bu hizmet, her yıl artarak devam etmektedir. Fakat şaşalı ve gösterişli iftarlardan kaçınıp öncelikli sarf alanlarını göz önünde bulundurmak temel hedef olmalıdır.

6. Mescitlerin 1sitılması ve havalandırılması: İnsanların hayat standartları günden güne değişmekte ve gelişmektedir. Soğuk ve sıcak hava insanların psikolojisini ve motivasyonunu doğrudan etkilemektedir. İnsanların ibadet esnasında huşu ve huzuru için bu iki problemin giderilmesi gerekir. Zira huşu ve huzur namazın özünü oluşturur. Günümüz hayır kurumları bu sebeple gelirlerinin bir kısmını bu alanda kullanmada bir sakınca görmemektedir.

7. Kur'an-1 Kerim ve Siyer-i Nebî yarışmalarını düzenlemek ve geliştirmek: Bu tür yarışmaları tertip etmek, doğrudan Kur'an'ın hıfzına, intişarına, Hz. Peygamber'in sevdirilmesine ve sünnetinin ihyasına yardım etmek demektir. Bu da hayır kurumlarının en büyük varlık sebeplerinden biridir. Gerçi böyle bir sarf kalemi yeni değil, eskiden beri var olagelmiştir. Fakat günümüzde bu iş daha organize bir şekilde yapılmakta ve daha fazla masraf gerektirmektedir.

8. İslami merkezleri desteklemek: İslami merkezler, dünyanın her yerinde özellikle de gayri Müslim beldelerde yayılmakta ve oralardaki Müslüman azınlıklar için iyilik ve ışık kaynağı olmaya çalışmaktadır. O merkezler sayesinde Müslümanlar birbirleriyle iletişim kurabilmekte, dini işlerini deruhte edebilmekte, hayır ve iyilikte yardımlaşabilmektedir. Dolayısıyla hayır kurumları tarafından bu tür ilim merkezleri ve çeşitli enstitüler desteklenmelidir $\mathrm{ki}$ toplum yararına olan faaliyetlerini sürdürebilsinler.

Hayır kurumları bu sayılanların haricinde deprem, yangın, sel, trafik kazaları vb. durumlarda zorda kalanlara maslahat temelinde yardım edebilir.

\section{Sonuç}

Hayır kurumları meşruiyetini, Kitap, Sünnet ve İcmâ'dan alan ve teberru akitleri kapsaminda değerlendirilen hükmi kişiliklere sahip yapılardır. Artan ve çeşitlenen toplumsal sorunların çözümünde ferdi gayretlerin yetersiz kalması neticesinde ortaya çıkan bu yapılar fert ve toplumun maslahatı temelinde faaliyette bulunmuşlardır. Son derece aktif ve dinamik olan bu müesseseler, İslam ülkelerinin mimârî ve estetik 
yapısından belediye hizmetlerine, eğitim-öğretiminden, iktisâdi, sosyal, siyasi ve askeri alanlarına varıncaya toplumun bütün katmanlarında önemli roller üstlenmişlerdir. Özellikle Osmanlılar döneminde hayır kurumları vakıflar aracılılığıyla bazı şehirleri adeta yeniden inşa etmişlerdir. Anadolu'nun birçok şehri bu yapıların mirası hükmündedir. Günümüzde faaliyet alanı daralan ve nisbeten âtıl duruma düşen hayır kurumlarının ve bilhassa vakıf şeklindeki yapıların desteklenmesinin zarureti ortadadır.

Hayır kurumlarının en temel gelirlerinden biri zekat, diğeri de sadakadır. Zekâtın sarf yerleri konusundaki yaklaşımların iki farklı temele dayandığ1 müşâhede edilmiştir. Bunlardan biri temlik, diğeri ise ibâha'dır. Zekâtın sarf alanıyla ilgili "temlik" şartını ileri sürenler, alanı dar tutarak onun sadece nas tarafindan belirlenen gruplara verilebileceğine hükmetmişlerdir. Çoğunluğun bu görüşü tercih ettiği görülmüştür. İbâha şartını ileri sürenler ise alanı alabildiğine geniş tutmuş, harcamanın mübah olduğu her yere zekâtın da verilebileceğine cevaz vermişlerdir. Bu görüş daha çok bazı muasır âlimler tarafından savunulmuştur. Fakat bu ikinci görüşü savunanların delillerin zayıf olduğunu söylemek mümkündür. Şu var ki Karâdâvî'nin mevzuyla ilgili yaklaşımı dikkat çekicidir. O, zekâtın sarf alanını nasla belirlenen sekiz gruptan biri olan "fisebîlillâh" ifadesinin içeriğinden hareketle "cihad edenler" olduğunu kabul etmiş ve bu konuda çoğunluğun görüşüne katılmıştır. Ancak cihâd" kavramının muhtevasını; ictimâî, iktisâdî siyâsî ve askerî alanı kapsayacak şekilde geniş tutmuştur. Dolayısıyla ona göre cihadın söz konusu olduğu alanlara zekât verilebilir. Bu amaca hizmet etmek şartıyla hükmü kişiliği olan bazı yapı ve kurumlar zekât fonuyla desteklenebilir.

Sadakanın sarf yerleri konusunda alan geniş tutulmuş, ihtiyacı olan kişilere sadaka verilebileceği gibi, hükmi kişiliği olan kurumlara, hatta prensipte canlı cansız tüm varlıklara sadakanın verilebileceği kabul edilmiştir. Bununla beraber sadakaların sarf alanları için öncelikli durumlar belirlenmiştir. Bu bağlamda sadakayı verenin beyan ve rızası temel ölçüt kabul edilmiştir. Onun bilgisi ve izni olmadan yapılan tasarruflar geçersiz sayılmıştır. Aynı şekilde teberru sahibi tarafından belirlenen kişi ve yerlerin dışındakilere sarf kapısı kapatılmış, öncelikli sarf yerleri belirlenmiş ve buna dair kurallar konmuştur. Bu manada fakir 
ve muhtaçlar dururken hayır amaçlı olsa dahi israfa kaçan aktivitelerden uzak durulması gerektiği sonucuna varılmıştır.

Hayır kurumları, satın alımlarda, kurumun malını satmada ya da borç vermede teberru sahipleri tarafından kendilerine verilen yetkiyi aşamayacakları genel ilke olarak kabul edildiği müşâhede edilmiştir. Ancak nakdî ve aynî yardımlar arasındaki farka dikkat çekilmiştir. Nakdî yardımlar konusunda teberru sahiplerinin yetkisi tartışılmazken aynî yardımlarda bu yetkinin bazı şartlara mebni olduğuna vurgu yapılmıştır. Zira aynî yardımların zaman içerisinde yıpranabileceği, asıl fonksiyonlarından uzaklaşabileceği, dolayısıyla toplumun maslahatı göz önünde bulundurularak ve teberru sahiplerinin de bilgisi dâhilinde üzerinde bazı değişikliklerin yapabileceği belirtilmiştir.

Sürekli değişen ve gelişen şartlar muvacehesinde Müslüman toplumların cehalet ve fakirlikle mücadele gibi temel sorunlarla baş edebilmesi için muasır âlimlerden bazıları zekât gelirleri de dâhil olmak üzere yapılan yardımlardan bir fon oluşturulmasını önermiştir. Bu fonda biriken meblağlarla fen, sanat ve marifet alanlarında imkânlar hazırlanmasını ve ekonomik sıkıntı çeken kişi ve kuruluşlara karz-ı hasen kapsamında borç verilerek yardımcı olunmasını bunun için de herhangi şer’i bir maninin bulunmadığını zikretmişlerdir. Şüphesiz cehalet ve fakirlikle mücadele adına böyle fonlara ihtiyaç vardır. Ancak fakihlerin çoğunluğu zekât gelirlerinin böyle fonlara aktarılmasını problemli görmüşlerdir. Nitekim gerek Hz. Peygamber dönemindeki uygulamalar gerekse âlimlerin konuyla ilgili yaklaşımları bizi zekât gelirlerinin harcama yerleri konusunda ihtiyatlı olmaya sevk etmektedir.

\section{Kaynakça}

Abdullah b. Nâsır es-Sudhân. Tevcîhu Mesârifi'l-vekf, nahve telbiyeti ihtiyâcâti'l-müctema'. Mekke-i Mükerreme: y.y., 2006.

Akgündüz, Ahmet. "İslâm Hukukuna Göre Vakıf Mallarının Mülkiyet Meselesi". Bakanlarda Osmanl Vakıfları ve Eserleri Uluslararası Sempozyumu. 13-29. Ankara: Vakıflar Genel Müdürlüğü Yayınları, 2012.

Aktaş, Beytüllah. Kur'an'a Göre Zekât'ın Harcama Kalemleri. İstanbul: İstanbul Üniversitesi, Sosyal Bilimler Enstitüsü, Doktora Tezi, 2013. Apaydın, H. Yunus. İslam Hukuk Usulü. Kayseri: Kimlik Yayınları, 2016. 
514 | A. CANER / Hayır Kurumlarının Gelirleri ve Bunların Sarf Yerleri

Atalay, Arif. “Teberru Akitlerinde Kabz". Universal Journal of Theology 5/1 (Haziran 2020), 1-18.

Aybakan, Bilal. “Temlik”. Türkiye Diyanet Vakfı İslam Ansiklopedisi.40/428430. İstanbul: TDV Yayınları, 2011.

Aybakan, Bilal. "Teberru". Türkiye Diyanet Vakfi İslam Ansiklopedisi. 40/215-216. İstanbul: TDV Yayınları, 2011.

Bardakoğlu, Ali. “Hibe”. Türkiye Diyanet Vakfı İslam Ansiklopedisi. 17/421426. İstanbul: TDV Yayınları, 1998.

Bay, Abdullah. Türkiye Mecmuası. 27/1 (2017), 47-64.

Bayyiğit, Mehmet. Sosyal Yardımlaşma ve Dayanışma Kurumu Olarak Vakıflar. Selçuk Üniversitesi İlahiyat Fakültesi Dergisi 11 (2001), 5966.

Buhârî, Ebû Abdillâh Muhammed b. İsmâil b. İbrâhim. el-Câmiu's-sahîh. thk. Muhammed Zuheyr. 8 Cilt. b.y.: Dâru Tavki'n-Necât, $1422 / 2001$.

Çağırıcı, Mustafa. "İnfak". Türkiye Diyanet Vakfı İslam Ansiklopedisi. 22/289-290. İstanbul: TDV Yayınları, 2000.

Dalgin, Nihat. "Zekât Hükümleri". OMÜ İlahiyat Fakültesi Dergisi 16/16 (2004), 43-72.

Diâ Âdil Kâsım es-Suknâ. el-Muessesâtu'l-hayriyye hukmuha ve devâbitu'lkâimîn aleyha ve hududu salahiyetihim. Gazze: el-Câmiatu'l-İslâmiyye, Yüksek Lisans Tezi, 2012.

Duman, Ali. "Sadaka". Türkiye Diyanet Vakfi İslam Ansiklopedisi. 35/383384. İstanbul: TDV Yayınları, 2008.

Ebû Dâvûd, Süleymân b. el-Eş'as b. İshâk es-Sicistânî el-Ezdî. Süneni Ebî Dâvîd. thk. Muhyiddîn Abdulhamîd. 4 Cilt. Beyrut: Mektebetu'1asriyye, ts.

Erkoç, Hatice. "Yusuf el-Karâdâvî'nin Fıkhu'z-Zekât Eseri Bağlamında "Fî Sebilillâh" Kavramı". Van İlahiyat Dergisi 8/13 (Aralık 2020), 193216.

Harşî, Muhammed b. Abdullâh. Şerhu Muhtasar Halil li'l-Harşî. 8 Cilt. Beyrut: Dâru'l-fikr, ts.

Ferâhîdî, Ebû Abdirrahmân el-Halil b. Ahmed b. Amr b. Temîm. Kitabu'l'Ayn. 4 Cilt. Beyrut: Mektebetü Lübnân Nâş̧irûn, ts.

Gazzâlî, Ebu Hâmid Muhammed b. Muhammed b. Muhammed b. Ahmed. İhyâu ulûmiddîn. 4 Cilt. Beyrut: Dâru'l-ma'rife, ts. 
Günay, Hacı Mehmet. "Vakıf”. Türkiye Diyanet Vakfı İslam Ansiklopedisi. 42/475-479. İstanbul: TDV Yayınları, 2012.

Hanîn Dît. Devru'l-müessesâtü'l-hayriyye fi't-tenmiyeti'l-ictimâiyye. Cezâyir: Câmi`atu eş-Şehîd Hama, Yüksek Lisans Tezi, 2015.

İbn Âbidîn, Muhammed Emîn b. Ömer b. Abdilazîz el-Hüseynî edDımaşkī. Reddü'l-muhtâr ale'd-dürri'l-muhtâr. 6 Cilt. Beyrut: Dâru'lfikr, 1992.

İbn 'Atiyye, Muhammed Nâcî. el-Binâu'l-müessisiyyu fi'l-münezzimâti'lhayriyye. Beyrut: Daru İbn Hazm, 1423.

İbn Kudâme, Ebü'l-Ferec Şemsüddîn Abdurrahmân b. Muhammed b. Ahmed el-Makdisî. Şerhu'l-kebîr alâ metni'l-Mukni'. 12 Cilt. b.y.: Dâru'l-kitâb, ts.

İbn Manzûr, Cemâlüddîn Muhammed b. Mükerrem b. Ali b. Ahmed elEnsârî er-Rüeyfî. Lisânü'l-'Arab. 6 Cilt. Kahire: Dâru'l-ma'rife, 1119. İbn Nüceym, Zeynüddîn b. İbrâhim b. Muhammed. el-Bahru'râik şerhu Kenzi'd-dekâik. 8 Cilt. b.y.: Dâru'l-kitâbi'l-İ̀slâm, ts.

İbn Teymiyye, Takıyyüddîn Ahmed b. Abdilhalîm b. Mecdiddîn Abdisselâm el-Harrânî. el-Kevâidu'n-nurâniyye el-fikhiyye. Memleketu'l-Arabiyyetu's-Suudiyye: Dâru İbnu'l-Cevzî, 1402.

İbnü'l-Humâm, Kemâlüddîn Muhammed b. Abdilvâhid b. Abdilhamîd es-Sivâsî el-İskenderî. Fethu'l-kadîr. 10 Cilt. b.y.: Dâru'l-fikr, ts.

İbnü's-Salâh, Takıyyüddîn Osmân b. Salâhiddîn Abdirrahmân b. Mûsâ eş-Şehrezûrî. Fetâvâ İbn Salâh. thk. Abdullah Abdulkadir. Beyrut: Mektebetu'l-'ulum, 1407.

İsfahânî, Ebu'l-Kâsım Hüseyin b. Muhammed. el-Müfredât fî garîbi'lKur'ân. b.y.: Dâru'l-kalem, 1412.

Karadâvî, Yusuf. Fıkhu'z-zekât. 2 Cilt. Kahire: y.y.,1985.

Karaman, Hayreddin. "Ayn", Türkiye Diyanet Vakfi İslam Ansiklopedisi. 4/257-258. İstanbul: TDV Yayınları, 1991.

Kâsânî, Alâüddîn Ebû Bekr b. Mes'ûd b. Ahmed. Bedâu's-Sanâi' fî tertibi'şşerâi' 7 Cilt. Beyrut: Dâru'l-kutubi'l-ilmiyye, 1986.

Köse, Murtaza. "Fî Sebîlillâh" Kavramının Zekât Açısından Tahlili". Atatürk Üniversitesi İlahiyat Fakültesi Dergisi, 21 (2004), 107-134.

Mahmud Şeltut. el-İslâm akidetun ve şerîatun. Kâhire: Dâru'ş-şurûk, 1968.

Mâlik b. Enes, Ebû Abdillâh b. Mâlik b. Ebî Âmir el-Asbahî el-Yemenî. elMüdevvene. 4 Cilt. Beyrut: Dâru'l-kutubi'l-ilmiyye, 1994. 
516 | A. CANER / Hayır Kurumlarının Gelirleri ve Bunların Sarf Yerleri

Mâverdî, Ebü'l-Hasen Alî b. Muhammed b. Habîb el-Basrî. el-Hâvi'l-kebîr.

19 Cilt. Beyrut: Dâru'l-kutubi'l-ilmiyye, 1999.

Merğinâni, Ebü'l-Hasen Burhânüddîn Alî b. Ebî Bekr b. Abdilcelîl el-

Fergānî. el-Hidâye fì şerhi Bidâye. thk. Talâl Yusuf. 4 Cilt. Beyrut:

Dâru ihyâ, ts.

Mevsilî̀, Abdullah b. Mahmud b. Mevdûd. el-İhtiyâr li ta'lîli'l-Muhtâr. 5 Cilt. Beyrut: Daru'l-kutubi'l-ilmiyye, 1937.

Müslim, Ebü'l-Hüseyn Müslim b. el-Haccâc b. Müslim el-Kuşeyrî. Sahîhu Müslim. thk. Muhammed Fuâd Abdulbâkî. 5 Cilt. Beyrût: Dâru İhyâ, ts.

Nesâî, Ebû Abdirrahmân Ahmed b. Şuayb b. Alî. Sünen. thk. Abdulfettâh Ebu Ğudde. 8 Cilt. Haleb: Mektebetü'l-matba'ati'l-İslâmiyye, 1986.

Nevevî, Ebû Zekeriyyâ Muhyiddîn Yahya b. Şeref. el-Mecmu' şerhu'lMuhezzeb. b.y.: Dâru'l-fikr, ts.

Remlî, Şihâbüddîn Ahmed b. Ahmed b. Hamza er-Remlî el-Menûfî elEnsârî. Nihâyetu'l-muhtâc ilâ şerhi'l-Minhâc. 8 Cilt. Beyrut: Dâru'lfikr, 1984.

Reşid Rıza. Tefsîru'l-Kur'ani'l-Hakîm. 12. Cilt. b.y.: el-Heyetu'l-Misriyye, 1990.

Said b. Ali b. Vehf el-Kathânî. Sadakatü't-tatavou' fi'l-İslâm. Riyad: Silsiletü'l-zakâti'l-muhsin, 1426.

Serahsi, Ebû Bekr Şemsü'l-eimme Muhammed b. Ebî Sehl Ahmed. elMebsût. 30 Cilt. Beyrut: Dâru'l-ma'rife, 1993.

Seyyid Kutub. Fîzilâli'l-Kur'an. 6 Cilt. Beyrut: Dâru'ş-şurûk, 1412.

Süleyman b. Câsir el-Câsir. Mesârifu'l-vekf fi'l-kadim ve'l-hadîs. Riyâd: Medâru'l-vatan li'n-neşr, 2014.

Şevkânî, Muhammed b. Alî b. Muhammed es-San'ânî el-Yemenî. esSeylu'l-cirâr el-mütedeffak alâ hadâiki'l-ezhâr. b.y.: Dâru İbn Hazm, ts.

Şîrâzi, Ebû İshâk Cemâlüddîn İbrâhîm b. Alî b. Yûsuf. el-Muhezzeb fi fikhi'l-İmâm eş-Şâfî̀. thk. Muhammed ez-Zuceylî. 3 Cilt. Beyrût: edDâru'Şâmiyye, 1992.

Tâberânî, Ebü'l-Kāsım Süleymân b. Ahmed b. Eyyûb. Mu'cemu's-să̆î̀r. 2 Cilt. Beyrut: Dâru İmâr, 1985.

Tirmizî, Ebû Îsâ Muhammed b. Îsâ b. Sevre. Sünen. thk. Ahmed Muhammed Şâkir - Ahmed Fuâd Abdulbâkî. 5 Cilt. Misır: Matb’atu Mustafa el-Bâbî, 1975. 
A. CANER / Income of Charitable Foundations and Where to Use Them I 517

Ubeyr Katmani. Müessesâtü'l-vakfiyye fi'l-Ahdi'l-Osmânî. b.y.: Mecelletu dirâseti Beyti'l-Makdis, 2017.

Öztürk, Nazif. "Evkâf-1 Hümâyun Nezâreti". Türkiye Diyanet Vakfı İslam Ansiklopedisi. 11/521-524. İstanbul: TDV Yayınları, 1995.

Yılmaz, Yasin. "Vakıf Kurumunun Dayandı̆̆ı Temel Referanslar ve Zürrî Vakıfların Vakıf Sistemindeki Yeri". Dini Araştırmalar 17/44 (Haziran 2014), 43-66. 